\title{
Fibroblast Growth Factor Receptors Cooperate to Regulate Neural Progenitor Properties in the Developing Midbrain and Hindbrain
}

\author{
Jonna Saarimäki-Vire, ${ }^{1}$ Paula Peltopuro, ${ }^{1}$ Laura Lahti, ${ }^{1}$ Thorsten Naserke, ${ }^{2,3}$ Alexandra A. Blak, ${ }^{2,3}$ \\ Daniela M. Vogt Weisenhorn, ${ }^{2,3}$ Kai Yu, ${ }^{4}$ David M. Ornitz, ${ }^{4}$ Wolfgang Wurst, ${ }^{2,3}$ and Juha Partanen ${ }^{1}$ \\ ${ }^{1}$ Institute of Biotechnology, Viikki Biocenter, University of Helsinki, 00014 Helsinki, Finland; ${ }^{2}$ National Research Center for Environment and Health, \\ Institute of Developmental Genetics, D-85764 Neuherberg, Germany, ${ }^{3}$ Max Planck Institute of Psychiatry, D-80804 Munich, Germany, and ${ }^{4}$ Department of \\ Molecular Biology and Pharmacology, Washington University Medical School, St. Louis, Missouri 63110
}

Fibroblast growth factors (FGFs) secreted from the midbrain-rhombomere 1 (r1) boundary instruct cell behavior in the surrounding neuroectoderm. For example, a combination of FGF and sonic hedgehog (SHH) can induce the development of the midbrain dopaminergic neurons, but the mechanisms behind the action and integration of these signals are unclear. We studied how FGF receptors (FGFRs) regulate cellular responses by analyzing midbrain-r1 development in mouse embryos, which carry different combinations of mutant Fgfr1, Fgfr2, and Fgfr3 alleles. Our results show that the FGFRs act redundantly to support cell survival in the dorsal neuroectoderm, promote $\mathrm{r}$ tissue identity, and regulate the production of ventral neuronal populations, including midbrain dopaminergic neurons. The compound Fgfr mutants have apparently normal WNT/SHH signaling and neurogenic gene expression in the ventral midbrain, but the number of proliferative neural progenitors is reduced as a result of precocious neuronal differentiation. Our results suggest a SoxB1 family member, Sox3, as a potential FGF-induced transcription factor promoting progenitor renewal. We propose a model for regulation of progenitor cell self-renewal and neuronal differentiation by combinatorial intercellular signals in the ventral midbrain.

Key words: fibroblast growth factor; isthmic organizer; midbrain; dopaminergic neuron; neural stem cell; SoxB1

\section{Introduction}

Development of structures derived from the embryonic midbrain and rhombomere $1(\mathrm{r} 1)$ is governed by a combinatorial action of intercellular signaling pathways. One source of such signals is the isthmic organizer ( $\mathrm{IsO}$ ), which is located at the midbrain-r1 boundary and secretes signaling molecules, including fibroblast growth factor (FGF) family members (Wurst and Bally-Cuif, 2001; Zervas et al., 2005; Rhinn et al., 2006). Knowledge of the cellular responses to these signals is important for both understanding normal brain development and devising strategies for therapeutic neuronal stem cell differentiation.

FGF signaling has been implied in several aspects of development in the midbrain and r1. Especially, FGF8 can transform cellular identities and induce development of ectopic midbrain and r1 structures (Nakamura et al., 2005; Zervas et al., 2005).

\footnotetext{
Received Jan. 17, 2007; revised May 4, 2007; accepted June 4, 2007.

This work was supported by the Academy of Finland, Biocentrum Helsinki, Sigrid Juselius Foundation, and Finnish Cultural Foundation (J.S.-V.); Helsinki Graduate School in Biotechnology and Molecular Biology (L.L., J.S.-V.); Viikki Graduate School in Biosciences (P.P.); and the Bundesministerium für Bildung und Forschung (NGFN2,01GS0476) and Deutsche Forschungsgemeinschaft (W.W.). We thank Eija Koivunen, Päivi Hannuksela, Marjo Virtanen, and Mervi Lindman for their expert technical assistance. We also thank Marjo Salminen and Klaus Unsicker for critical comments on this manuscript, Thomas Edlund for the anti-Sox3 antibodies, and Michael German for the anti-LMX1a antibodies.

Correspondence should be addressed to Juha Partanen, Institute of Biotechnology, Viikki Biocenter, University of Helsinki, P.0. Box 56, 00014 Helsinki, Finland. E-mail: juha.m.partanen@helsinki.fi.

DOl:10.1523/JNEUROSCI.0192-07.2007

Copyright $\odot 2007$ Society for Neuroscience $\quad$ 0270-6474/07/278581-12\$15.00/0
}

Conditional inactivation of $F g f 8$ in the midbrain-r1 region results in apoptotic cell death and a failure in development of both dorsal and ventral brain structures (Chi et al., 2003). FGF signaling in the midbrain and $\mathrm{r} 1$ may control cell proliferation and differentiation of specific neuronal cell types (Ye et al., 1998; Xu et al., 2000; Trokovic et al., 2005). In a rat midbrain explant culture model, FGF8 and sonic hedgehog (SHH) can promote the development of dopaminergic (DA) neurons, whereas inhibition of FGF signaling blocks it (Ye et al., 1998). However, whether and how FGFs regulate the production of the DA neurons in vivo still remains open.

During the midbrain-r1 development in the mouse, FGF receptors Fgfr1, Fgfr2, and Fgfr3 are expressed (Liu et al., 2003; Blak et al., 2005; Trokovic et al., 2005); Fgfrl transcripts are abundant in the entire midbrain and $\mathrm{r} 1$, whereas Fgfr2 and Fgfr3 are not detected at the midbrain-r1 boundary. Consistently, conditional inactivation of $F g f r 1$ results in midbrain and $r 1$ defects (Trokovic et al., 2003, 2005; Jukkola et al., 2006), whereas inactivation of Fgfr2 or Fgfr3 alone does not interfere with the development of this brain region (Blak et al., 2006). Compared with the conditional Fgf8 mutants, however, the phenotype of the conditional Fgfrl mutants is clearly less severe (Trokovic et al., 2003; Jukkola et al., 2006). Target genes of FGF signaling are still expressed in the midbrain and $\mathrm{r} 1$ of the Fgfrl mutants, except in the cells near the midbrain-r1 border (Trokovic et al., 2003, 2005). Because these regions overlap with $F g f r 2$ and $F g f r 3$ expression, it is possi- 
Table 1. Summary of the midbrain-r1 defects observed in Fgfr compound mutant embryos

\begin{tabular}{|c|c|c|c|}
\hline \multirow[b]{2}{*}{ Genotype } & \multicolumn{3}{|l|}{ Phenotype } \\
\hline & $\mathrm{E} 9.5$ & $\mathrm{E} 12.5$ & $\mathrm{E} 18.5$ \\
\hline $\mathrm{Fgfr}^{\mathrm{cko}}$ & Boundary defect & DA disorganized; DR reduced & $\begin{array}{l}\text { Ve, IC deleted; DA, LC disorganized; DR re- } \\
\text { duced }\end{array}$ \\
\hline Fgfr2 $2^{c k o}$ & n.a. & - & - \\
\hline Fgfr3 $3^{\text {null }}$ & n.a. & - & - \\
\hline Fgfr $^{c k o}, F g f r 2^{c k o}$ & $\begin{array}{l}\text { Apoptosis, mispatterning, no ls0 } \\
\text { gene expression dorsally }\end{array}$ & DA decreased; DR deleted & Cerebellum, SC, IC, DA, LC, III, IV, DR deleted \\
\hline $\mathrm{Fgfr}^{\mathrm{cko}}, \mathrm{Fgfr}^{\mathrm{null}}$ & n.a. & n.a. & $\begin{array}{l}\text { Ve, IC deleted; DA, LC disorganized; DR re- } \\
\text { duced }\end{array}$ \\
\hline $\mathrm{Fgfr}_{2}{ }^{\mathrm{cko}}, \mathrm{Fgfr}^{\text {null }}$ & n.a. & n.a. & - \\
\hline $\mathrm{Fgfr}^{\mathrm{cko}}{ }^{\prime} \mathrm{Fgfr}^{\mathrm{cko}}, \mathrm{Fgfr}^{\text {null }}$ & $\begin{array}{l}\text { Apoptosis, mispatterning, no ls0 } \\
\text { gene expression }\end{array}$ & DA decreased; DR deleted & $\begin{array}{l}\text { Cerebellum, PPT, SC, IC, DA, LC, III, IV, DR } \\
\text { deleted }\end{array}$ \\
\hline
\end{tabular}

III, Oculomotor nucleus; IV, trochlear nucleus; DR, serotonergic neurons of the dorsal raphe; IC, inferior colliculus of the midbrain; LC, locus ceruleus; PPT, posterior pretectum; SC, superior colliculus of the midbrain; Ve, vermis of the cerebellum (medial cerebellum); n.a., not analyzed; -, no phenotypical defects observed.

ble that in Fgfr1 mutants, either FGFR2, FGFR3, or both mediate residual FGF signaling.

Here, we have generated mice carrying different combinations of Fgfr1, Fgfr2, and Fgfr3 mutations. Our results demonstrate partly redundant contributions of the three FGF receptors in receiving signals from the $\mathrm{IsO}$, regulating cell survival, and patterning in the developing midbrain and $\mathrm{r} 1$. In addition, we suggest that FGF signaling through these receptors in the ventral midbrain controls SoxB1 activity and the decisions about the neural progenitor cell proliferation versus differentiation. Distinct signaling pathways need to be integrated to regulate selfrenewal, cell identity, and postmitotic differentiation of neural progenitors into neuronal subtypes, such as DA neurons.

\section{Materials and Methods}

Generation and genotyping of mice and embryos. Generation and genotyping of an Engrailed 1 (En1) allele carrying Cre-recombinase knock-in (Kimmel et al., 2000), a conditional Fgfrl allele (Trokovic et al., 2003), a conditional Fgfr 2 allele (Yu et al., 2003), and a Fgfr3 null allele (Colvin et al., 1996) have been described previously. All of the alleles were maintained in an outbred genetic background (ICR).

Mice carrying these alleles were intercrossed to generate $\mathrm{En1} 1^{\mathrm{Cre} /+}$; Fgfr $1^{\text {flox/flox }}\left(\mathrm{Fgfr} 1^{\text {cko }}\right), \quad$ En $1^{\mathrm{Cre} /+} ; \mathrm{Fgfr} 2^{\text {flox/flox }}\left(\mathrm{Fgfr} 2^{\text {cko }}\right), \quad \mathrm{Fgfr} 3^{\text {null } / \text { null }}$ $\left(\mathrm{Fgfr} 3^{\text {null }}\right), \mathrm{En1} 1^{\mathrm{Cre} /+} ; \mathrm{Fgfr} 1^{\text {flox/flox }} ; \mathrm{Fgfr} 2^{\text {flox/flox }}\left(\mathrm{Fgfr} 1^{\text {cko }} ; \mathrm{Fgfr} 2^{\text {cko }}\right), \mathrm{En1} \mathrm{Crel}^{\mathrm{Cr}}$; Fgfr $1^{\text {flox/flox }} ; \mathrm{Fgfr} 3^{\text {null/null }} \quad\left(\mathrm{Fgfr} 1^{\text {cko }} ; \mathrm{Fg} f \mathrm{rr} 3^{\text {null }}\right), \quad \mathrm{En} 1^{\mathrm{Cre} /+} ; \mathrm{Fgfr} 2^{\text {flox/flox; }}$ $\mathrm{Fgfr} 3^{\text {null } / \text { null }}\left(\mathrm{Fgfr} 2^{\text {cko }} ; \mathrm{Fgfr} 3^{\text {null }}\right)$, and $\mathrm{En1}{ }^{\mathrm{Cre} /+} ; \mathrm{Fgfr} 1^{\text {flox/flox }} ; \mathrm{Fg} f r 2^{\text {flox/flox; }}$; Fgfr $3^{\text {null } / \text { null }}\left(\right.$ Fgfr $\left.^{\text {cko }} ; F_{\text {Ffr }} 2^{\text {cko }} ; F_{g f r} 3^{\text {null }}\right)$ embryos.

Noon of the day of a vaginal plug was designated as the embryonic day 0.5 (E0.5). Embryonic age was determined more precisely by counting somites. Histological procedures are described in detail in the supplemental material (available at www.jneurosci.org).

Analysis of cell death. To identify apoptotic cells, terminal deoxynucleotidyl transferase-mediated biotinylated UTP nick end labeling (TUNEL) analyses were performed with the In situ Cell Death Detection kit (Roche Diagnostics, Indianapolis, IN) on paraffin sections according to the manufacturer's instructions and on whole embryos as described previously (Chi et al., 2003). Statistical significance of the observed differences in the numbers of apoptotic cells in wild-type and mutant embryos was analyzed with Student's one-tailed $t$ test.

$m R N A$ in situ hybridizations. Whole-mount mRNA in situ hybridization analysis of E8.5-E11.5 embryos was performed as described previously (Henrique et al., 1995) using digoxigenin-labeled antisense RNA probes. Radioactive mRNA in situ hybridization analyses on paraffin sections were performed as described previously (Wilkinson and Green, 1990) using ${ }^{35}$ S-labeled RNA probes.

Immunohistochemistry and cell proliferation assays. For bromodeoxyuridine (BrdU) incorporation analyses, a single intraperitoneal injection of BrdU labeling mix ( $1 \mathrm{ml} / 100 \mathrm{~g}$ of body weight; GE Healthcare,
Piscataway, NJ) was given to females $2 \mathrm{~h}$ before dissecting the embryos. Antibodies used for immunohistochemistry were rabbit anti-ALDH1 (1:500; Abcam, Cambridge, UK), mouse anti-BrdU (1:400; GE Healthcare), mouse anti-HuC/D (1:500; Invitrogen, Eugene, OR), rabbit antiLMX1a (1:300; from Michael German, University of California at San Francisco, San Francisco, CA), rabbit anti-SOX2 (1:500; Millipore), rabbit anti-SOX3 (1:500; from Thomas Edlund, Umeå University, Umeå, Sweden), and rabbit and mouse anti-tyrosine hydroxylase (TH; 1:500; Millipore). Goat anti-rabbit IgG (1:300; Alexa-488; Invitrogen) and goat anti-mouse IgG (1:400; Alexa-488 and Alexa 568; Invitrogen) were used as secondary antibodies. Immunohistochemical staining of paraffin sections was performed as described previously (Jukkola et al., 2006).

\section{Results \\ Anatomical defects in the midbrain and rhombomere 1 derivatives of the compound Fgfr mutants}

To address the possible redundancy among Fgfr $1, F g f r 2$, and $\mathrm{Fgfr} 3$ in the regulation of the midbrain-r1 development, we generated embryos carrying different combinations of $E n 1^{\text {cre }}$, conditional Fgfr1 $\left(F g f r 1^{f l o x}\right)$, conditional Fgfr2 $\left(F g f r 2^{f l o x}\right)$, and Fgfr3 null $\left(F g f r 3^{\text {null }}\right)$ alleles (Table 1, Fig. 1). The Crerecombinase-mediated inactivation of Fgfrl and Fgfr2 gene expression in the midbrain and $\mathrm{r} 1$ was observed between E8.5 and E9.5 [by 10 somite stage (ss) in the case of Fgfr 1 (Trokovic et al., 2003; Blak et al., 2006) (supplemental Fig. S1, available at www.jneurosci.org as supplemental material)]. In contrast to the Fgfrl mutants, in which Fgfrl was conditionally inactivated by $E n 1^{c r e}$ (hereafter referred to as $F g f r 1^{c k o}$ ) (Trokovic et al., 2003), neither the conditional inactivation of Fgfr2 by $E n 1^{\text {cre }}\left(F g f r 2^{c k o}\right)$ nor the null mutation of Fgfr3 $\left(F g f r 3^{\text {null }}\right)$ disturb the normal development of the midbrain-r1 region ( $\mathrm{Ta}-$ ble 1) (Blak et al., 2006). Even Fgfr $2^{\text {cko }} ; F g f r 3^{\text {null }}$ mutants had no defects at E18.5 (Fig. 1C). Thus, FGFR1 clearly is the primary FGF receptor receiving signals from the IsO.

However, the other FGFRs play a role as well. The phenotype of E18.5 Fgfr1 ${ }^{c k o} ; \mathrm{Fgfr} 2^{c k o}$ mutants was strikingly more severe than that of the Fgfr ${ }^{c k o}$ mutants (Fig. $1 B, D$ ). Unlike the Fgfr $1^{c k o}$ mutants, the $F g f r 1^{c k o} ; F g f r 2^{c k o}$ mutants did not survive after birth. In the $\mathrm{Fgfr}^{\text {cko }}$;Fgfr $2^{\text {cko }}$ mutants, most of the dorsal midbrain, including the superior and inferior colliculi, was deleted. Similarly, whereas the Fgfr $1^{\text {cko }}$ embryos lack only the vermis of the cerebellum, derived from the dorsoanterior $\mathrm{r} 1$, the $\mathrm{Fg} f \mathrm{r} 1^{\text {cko }} ; \mathrm{Fg} f \mathrm{r} 2^{\text {cko }}$ double mutants lack the entire cerebellum. In addition to these dorsal derivatives of the midbrain and $\mathrm{r} 1$, the developmental defects of many of the ventrally derived nuclei were clearly more severe in the Fgfr ${ }^{c k o} ; \mathrm{Fgfr} 2^{\text {cko }}$ mutants than in the Fgfr $1^{\text {cko }}$ mutants (Table 1; 

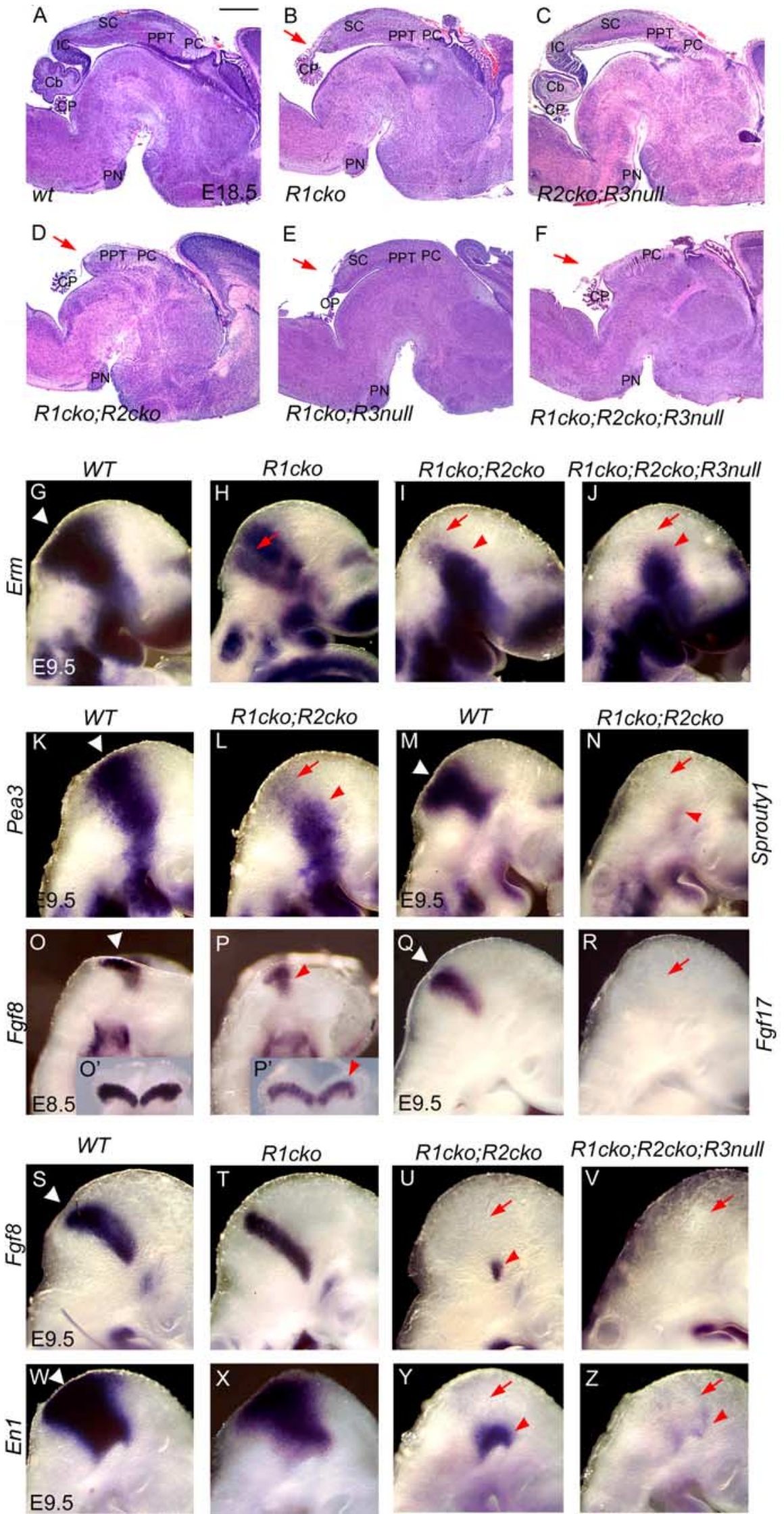

Figure 1. Anatomical defects and FGF target gene expression in the compound Fgfr mutants. $\boldsymbol{A}-\boldsymbol{F}$, Midsagittal sections of

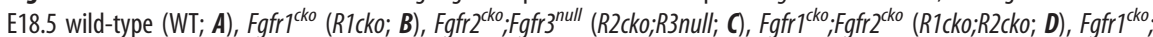

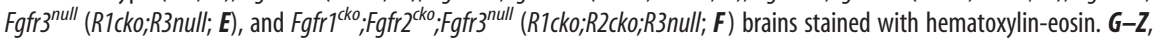
Expression of FGF signaling target genes Erm $(\mathbf{G}-\boldsymbol{J})$, Pea3 $(\boldsymbol{K}, \boldsymbol{L})$, and Sprouty $(\boldsymbol{M}, \boldsymbol{N}), F g f 8\left(\mathbf{O}, \boldsymbol{P}, \mathbf{S}-\boldsymbol{V}\right.$; dorsal view, $\left.\mathbf{O}^{\prime}, \boldsymbol{P}^{\prime}\right)$, Fgf17 see below). In contrast, we did not observe phenotypical differences between the Fgfr $1^{\text {cko }} ; \mathrm{Fgfr} 3^{\text {null }}$ and $F g f r 1^{\text {cko }}$ mutants at E18.5 (Fig. $1 B, E$ ).

The phenotype of E18.5 Fgfr $1^{\text {cko }}$; $\mathrm{Fgfr}^{\text {cko }} ; \mathrm{Fgfr} 3^{\text {null }}$ triple mutants resembled that of the Fgfr1 ${ }^{c k o} ; F g f r 2^{\text {cko }}$ double mutants, but only in the triple mutants did the dorsal deletion include the posterior pretectum (Fig. 1D,F). The deletions in the ventral brain region may also be more severe in the triple mutants, but this phenotypic characteristic was difficult to measure quantitatively. More convincing differences between the $\mathrm{Fgfr}^{\text {cko }} ; \mathrm{Fgfr} 2^{\text {cko }} ; \mathrm{Fgfr} 3^{\text {null }}$ and $\mathrm{Fgfr} 1^{\text {cko }}$; $\mathrm{Fgfr} 2^{\text {cko }}$ mutants were seen in the early gene expression patterns and numbers of DA neurons (see below). Overall, the phenotype of the Fgfr1 ${ }^{\text {cko }}$; Fgfr $2^{\text {cko }}$; Fgfr $3^{\text {null }}$ mutants at E18.5 appeared very similar to the Fgf8 conditional mutants (Chi et al., 2003).

\section{FGF target gene expression}

To study the effects of Fgfr mutation on FGF signaling in embryos, we analyzed the expression of the Ets-family transcription factors Erm and Pea3, as well as the feedback antagonist Sprouty1 (Spry1). All of these genes are considered to be general and early transcriptional targets of the FGF signaling pathway. Compared with the wild type, in $F g f r 1^{c k o} ; F g f r 2^{c k o}$ double mutants Erm (Fig. $1 G, I$ ), Pea3 (Fig. $1 K, L$ ), and Spry1 (Fig. $1 M, N$ ) were markedly downregulated by E9.0 (20-23 somite stage). This is in contrast with the same stage Fgfr $1^{c k o}$ mutants, in which these genes are downregulated only in a narrow stripe of cells close to the midbrain-r1 boundary (Fig. 1H) (Trokovic et al., 2005). In the Fgfr1 ${ }^{\text {cko }} ; \mathrm{Fg} f \mathrm{r}^{\text {cko }}$ mutants, some expression of Erm still existed in the ventral neuroectoderm at the midbrain-r1 boundary (supplemental Fig. S2P, available at www.jneurosci.org as supplemental material). In contrast, we found no neuroectodermal Erm expression in the Fgfr ${ }^{c k o}$;

$(\boldsymbol{Q}, \boldsymbol{R})$, and $E n 1(\boldsymbol{W}-\boldsymbol{Z})$ in WT, Fgfr ${ }^{\mathrm{cko}} ; F_{g f r}{ }^{c k o}$, and $F g f r 1^{c k o}$; $\mathrm{Fgfr}^{\mathrm{cko}}$; $\mathrm{Fgfr} 3^{\text {null }}$ embryos as detected by whole-mount in situ hybridization at E8.5 (11 ss)-E9.5 (20-23 ss). Red arrows indicate dorsal structures that are affected in mutant brains and loss of gene expression in mutant embryos. Red arrowheads point to ventral expression domains that remain in $\mathrm{Fgfr}^{\mathrm{cko}} ; \mathrm{Fgfr}^{\text {cko }}$ and $\mathrm{Fgfr}^{\mathrm{cko}} ; \mathrm{Fgfr}^{\mathrm{cko}} ; \mathrm{Fgfr}^{\text {null }}$ mutants. White arrowheads mark the location of the midbrain- $r 1$ border in WT embryos in all of the figures. Cb, Cerebellum; $C P$, choroid plexus; IC, inferior colliculus; PC, posterior commissure; PN, pontine nuclei; PPT, posterior pretectal nucleus; SC, superior colliculus. Scale bar, $1 \mathrm{~mm}$. 
Fgfr $2^{\text {cko }} ; \mathrm{Fgfr} 3^{\text {null }}$ mutants at the same stage (E9.5, 23 ss) (Fig. 1J; supplemental Fig. S2Q, available at www.jneurosci.org as supplemental material).

Next, we analyzed the expression of other downstream targets of FGF signaling, such as Fgf8, Fgf17, and Fgf18 themselves, as well as En1. In contrast to the Fgfr $1^{\text {cko }}$ mutants (Fig. 1T,X), the expression of all of these genes was abolished in the Fgfr ${ }^{\text {cko }} ; \mathrm{Fg} f r 2^{\text {cko }}$ embryos between E8.5 (11 ss) (Fig. 1O,P) and E9.5 (20-25 ss) (Fig. 1Q-Z) (data not shown), except for a small ventral domain. Similarly to the Erm expression, the downregulation of both Fgf8 and En1 in the Fgfr $1^{\text {cko }} ; \mathrm{Fgfr} 2^{\text {cko }}$; Fgfr $3^{\text {null }}$ mutants at the same stage was even more striking and almost complete (Fig. $1 V, Z$ ). Thus, the inactivation of all Fgfr1, Fgfr2, and Fgfr3 results in an early failure in IsO signaling. Also, the comparison of the gene-expression patterns between $F g f r 1^{c k o} ; F g f r 2^{c k o}$ and $F g f r 1^{c k o}$; $F g f r 2^{\text {cko }} ; \mathrm{Fgfr} 3^{\text {null }}$ mutants reveals a role for Fgfr3, especially in the ventral midbrain-r1 region.

\section{Cell death}

Because the loss of IsO signaling in the conditional Fgf8 mutant and in the Wnt1 null mutant embryos results in elevated cell death at E8.5-E9.5 (Chi et al., 2003), we next analyzed apoptotic cell death in the compound Fgfr mutants. Wholemount TUNEL staining revealed an increased number of apoptotic cells in the dorsal midbrain-r1 region of $F g f r 1^{c k o}$; $\mathrm{Fgfr}^{\text {cko }}$ and $\mathrm{Fgfr}^{\text {cko }} ; \mathrm{Fgfr} 2^{\text {cko }} ; \mathrm{Fgfr} 3^{\text {null }}$ embryos at E8.5-E9.0 (12 and 16-18 ss) (Fig. 2A-I).

To further quantify the apoptotic cell death, we performed TUNEL staining on sections of E9.0 (17-20 ss) wild-type and Fgfr $1^{\text {cko }} ; \mathrm{Fgfr} 2^{\text {cko }}$ double-mutant embryos. To determine the borders of the midbrain-r1 region, parallel sections were hybridized with Pax6 and HoxA2 probes (data not shown). Compared with wild type $(n=2)$, the number of apoptotic cells was increased in the dorsal midbrain-r1 region of the $F g f r 1^{\text {cko }} ; F g f r 2^{\text {cko }}$ embryos $(n=3 ; p<0.05)$ (Fig. $2 P-R)$. Cleaved caspase 3 staining and analysis of semithin plastic sections at E9.0 (14-20 ss) (Fig. $2 J-O)$ (data not shown) also revealed apoptotic cells and a loss of epithelial morphology, especially in the dorsal midbrain-r1 tissue. Thus, the increased cell death presumably contributes to the loss of dorsal midbrain and $\mathrm{r} 1$ derivatives. In the ventral midbrain-rl of the $F g f r 1^{\text {cko }}$; Fgfr ${ }^{c k o}$ mutants, the apoptotic cell death showed a small but statistically significant
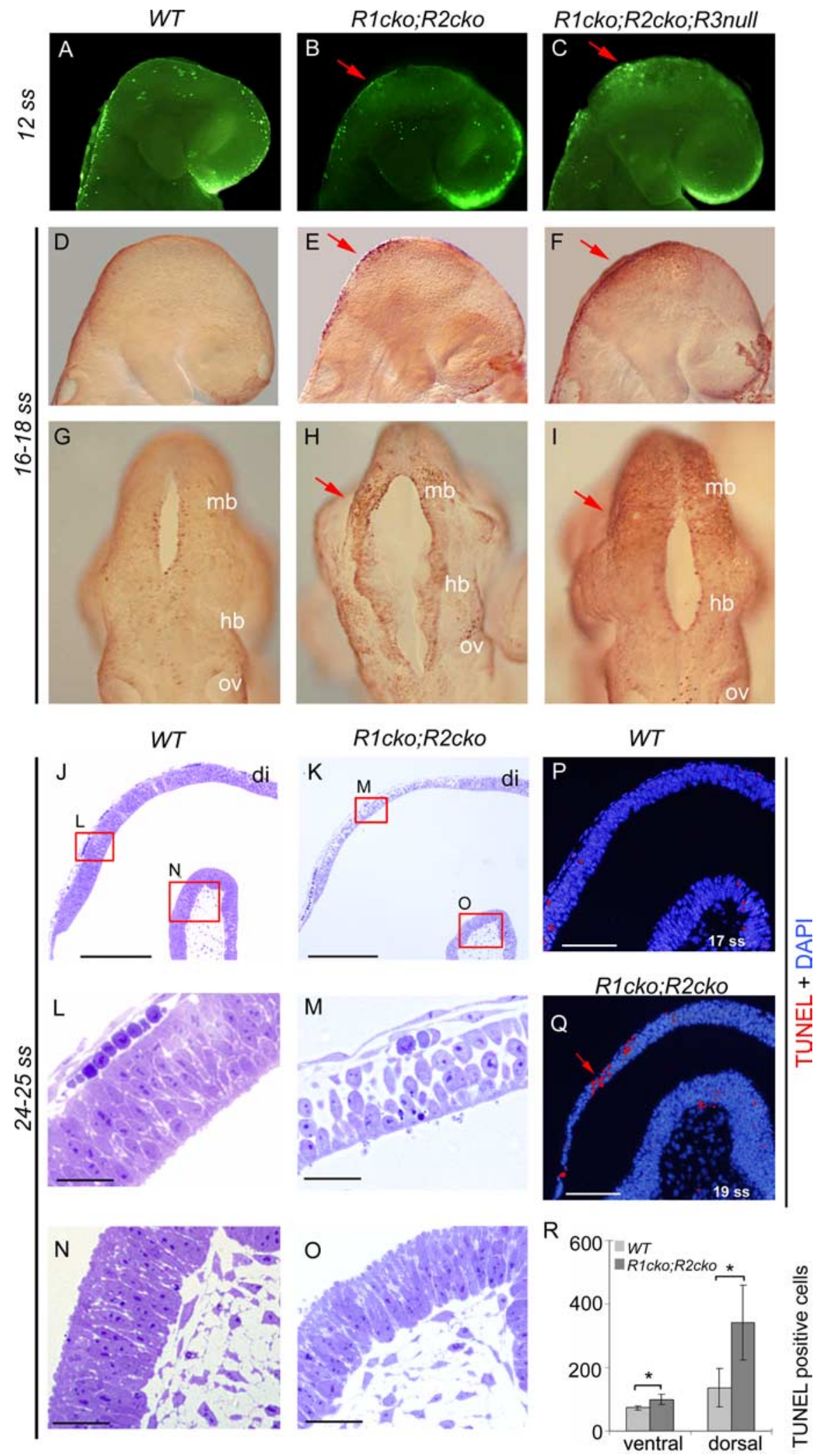

Figure 2. Increased apoptotic cell death in the dorsal midbrain-r1 region. $\boldsymbol{A}-\boldsymbol{I}$, Increased apoptosis is detected by TUNEL

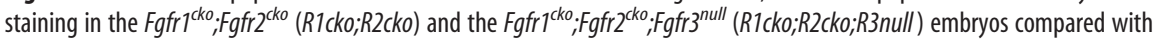
wild-type (WT). J-0, Sagittal semithin sections of the E9.0 WT $(\boldsymbol{J}, \boldsymbol{L}, \boldsymbol{N})$ and $F g f r{ }^{c k o}$; $F g f r{ }^{c k o}(\boldsymbol{K}, \boldsymbol{M}, \mathbf{0})$ dorsal midbrain-r1 region. $\boldsymbol{L}-\mathbf{0}$, Close-ups of dorsal and ventral midbrain of WT $(\boldsymbol{L}, \boldsymbol{N})$ and $F g f r 7^{c k o} ; F g f r 2^{c k o}(\boldsymbol{M}, \mathbf{0})$ embryos. $\boldsymbol{P}-\boldsymbol{R}$, The number of apoptotic cells was quantified (mean of total number \pm SD) separately from ventral and dorsal midbrain-r1 regions of TUNEL-stained paraffin sections. Red arrows indicate an increased number of apoptotic cells. Mb, Midbrain; hb, hindbrain; ov, optic vesicle; di, diencephalon; DAPI, 4', $6^{\prime}$-diamidino-2-phenylindole. ${ }^{*} p<0.05$, analyzed by Student's $t$ test. Scale bars: J, $\boldsymbol{K}, 200 \mu \mathrm{m} ; \boldsymbol{L}-\mathbf{0}, 30$ $\mu \mathrm{m} ; \boldsymbol{P}, \mathbf{Q}, 100 \mu \mathrm{m}$. 

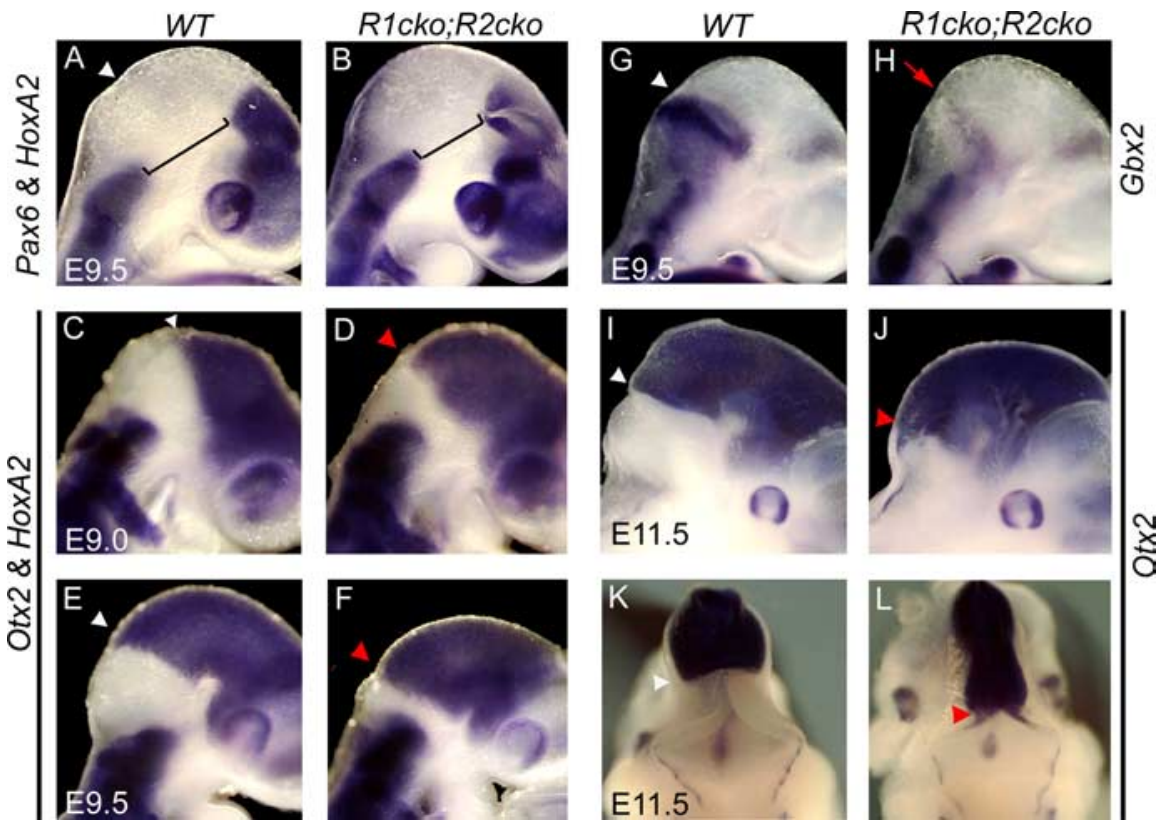

Figure 3. Partial $r$ 1-to-midbrain transformation. Whole-mount mRNA in situ hybridization analysis of $\operatorname{Pax6}$ and $\operatorname{HoxA2}(\boldsymbol{A}, \boldsymbol{B})$, Otx2 and HoxA2 (C-F), Gbx2 (G, $\boldsymbol{H})$, and Otx2 (I-L) expression in wild-type and Fgfr ${ }^{c k o} ; F g f r 2{ }^{c k o}(R 1 c k o ; R 2 c k o)$ embryos $\boldsymbol{A}-\boldsymbol{J}$, Lateral views; $\boldsymbol{K}, \boldsymbol{L}$, dorsal views. $\boldsymbol{A}, \boldsymbol{B}$, Brackets indicate the decreased size of the midbrain-r1 region in the mutants. Red arrowheads indicate a caudal shift of Otx2 expression toward $\mathbf{r} 2 . \boldsymbol{H}$, Red arrow indicates change of gene expression in $r 1$. tants still have a considerable amount of midbrain-r1 tissue. We therefore wanted to analyze how neuronal differentiation was affected in these mutants, especially in the ventral region, in which apoptotic cell death was not prominent at the early stages.

We found no TH-positive DA neurons in the ventral midbrain of E18.5 Fgfr1 ${ }^{\text {cko }}$; $\mathrm{Fgfr}^{\text {cko }}$ and $\mathrm{Fgfr}^{\text {cko }} ; \mathrm{Fgfr} 2^{\text {cko }} ; \mathrm{Fgfr} 3^{\text {null }} \mathrm{em}-$ bryos (Fig. $4 A, B$ ) (data not shown). Analyses for dopamine transporter (Dat), Pitx3, and Nurr1 expression confirmed these results (data not shown). In contrast, Fgfr $1^{\text {cko }} ; \mathrm{Fgfr} 3^{\text {null }}$ mutants had abundant but disorganized DA neurons in the ventral midbrain (data not shown), similarly to the Fgfr ${ }^{\text {cko }}$ mice (Jukkola et al., 2006). In addition, both in the $F g r r 1^{c k o} ; F g f r 2^{c k o}$ and $\mathrm{Fgfr}^{\text {cko }} ; \mathrm{Fgfr}^{\text {cko }} ; \mathrm{Fgfr} 3^{\text {null }}$ embryos at E18.5, noradrenergic neurons of the locus ceruleus, serotonergic neurons of the dorsal raphe nuclei, and the oculomotor and trochlear motor nuclei, were lacking (supplemental Fig. S2 A-N, available at www. jneurosci.org as supplemental material). increase compared with the wild-type embryos $(p<0.05)$ (Fig. $2 R)$.

\section{Anteroposterior patterning}

FGF signaling is considered to be involved in establishment of the anterior border of the midbrain and the posterior border of the $\mathrm{r} 1$, as well as in the maintenance of the midbrain-r1 border position (Zervas et al., 2005). To determine the borders of the midbrain-r1 region in the Fgfr $1^{c k o} ; F g f r 2^{c k o}$ embryos, we performed a whole-mount in situ hybridization with probes for Pax6, expressed anteriorly in diencephalon, and HoxA2, expressed posteriorly in $\mathrm{r}$ 2. In E9.5 Fgfr $1^{c k o} ; \mathrm{Fg} f r 2^{\text {cko }}$ mutants, the size of the midbrain-r1 domain appeared reduced, but Pax6 and HoxA2 expression domains showed no clear signs of spreading or enlargement (Fig. $3 A, B$ ). Thus, midbrain-diencephalic and r1-r2 borders appear correctly established in the Fgfr $1^{c k o} ; \mathrm{Fgfr} 2^{\text {cko }} \mathrm{mu}-$ tants. However, in the $F g f r 1^{c k o} ; F g f r 2^{c k o} ; F g f r 3^{\text {null }}$ mutants, the expansion of the posterior commissure (Fig. $1 F$ ), a structure of dorsal diencephalon, may indicate a posterior shift of the midbrain-diencephalic border.

FGF signals from IsO are also thought to inhibit Otx2 expression and thus promote $\mathrm{r} 1$ fate and restrict the expansion of the midbrain (Zervas et al., 2005). Consistent with this, in Fgfr $1^{\text {cko }}$; Fgfr $2^{c k o}$ embryos at E9.0-E9.5 (Fig. 3C-F) and at E11.5 (Fig. $3 I-L)$, the border of Otx2 expression shifted posteriorly. Simultaneously, $G b \times 2$ expression in the anterior $\mathrm{r} 1$ was downregulated (Fig. 3G,H). Double in situ hybridization with Otx2 and HoxA2, expressed in the midbrain and $\mathrm{r} 2$, respectively, revealed that at E9.0-9.5 (16 ss and 22-23 ss) (Fig. 3C-F) (data not shown), the entire $\mathrm{r} 1$ was not deleted or transformed into midbrain identity, but a small domain negative for Otx 2 and HoxA2 persisted both in $\mathrm{Fgfr}^{\text {cko }} ; \mathrm{Fgfr} 2^{\text {cko }}$ and $\mathrm{Fgfr} 1^{\text {cko }} ; \mathrm{Fgfr} 2^{\text {cko }} ; \mathrm{Fgfr} 3^{\text {null }}$ embryos.

\section{Development of neuronal populations in the ventral} midbrain-r1 region

Based on the expression of the regional marker genes, such as Pax6, Otx2, En1 and HoxA2, the E9.5-E11.5 Fgfr ${ }^{\text {cko }}{ }^{F g f r 2}{ }^{\text {cko }} \mathrm{mu}-$

\section{Development of the dopaminergic neuron precursors}

Because apoptotic cell death or identity transformation seemed unlikely to fully explain the loss of DA neurons in the ventral midbrain, we analyzed their development in the mutants in more detail. Interestingly, in the $F g f r 1^{\text {cko }} ; F g f r 2^{\text {cko }}(n=5)$ and $F g f r 1^{\text {cko }}$; $F g f r 2^{\text {cko }} ; \mathrm{Fgfr}^{\text {null }}(n=3)$ embryos at E12.5, few TH-positive neurons existed, although compared with the wild type $(n=7)$ and $F g f r 1^{c k o}(p<0.01)$ (Fig. $\left.4 F-J\right)$, their amount was clearly reduced. Between the $\mathrm{Fgfr}^{\text {cko }} ; \mathrm{Fgfr} 2^{\text {cko }}$ and $\mathrm{Fgfr}{ }^{\text {cko }} ; \mathrm{Fgfr} 2^{\text {cko }} ; \mathrm{Fgfr} 3^{\text {null }}$ mutants, the number of TH-positive neurons differed ( $p<0.01)$, as well. Because virtually no TH-positive cells existed in the ventral midbrain of $\mathrm{Fgfr}^{\text {cko }} ; \mathrm{Fgfr} 2^{\text {cko }}$ mutants at E15.5 (Fig. $\left.4 \mathrm{C}-\mathrm{E}\right)(n=$ $3)$, they are lost soon after E12.5

To test the idea that the residual TH-positive cells may result from an incomplete Cre recombination, we analyzed Fgfrl expression in E12.5 Fgfr $1^{\text {cko }}$; Fgfr $2^{\text {cko }}$ mutant midbrain (Fig. 4T,V). We observed scattered Fgfr 1 -expressing cells dorsally. These cells may have their origin outside the midbrain and may have moved into this region after the apoptotic death of the dorsal midbrain, because no Fgfrl-expressing cells exist in the dorsal midbrain at earlier stages in either Fgfr $1^{c k o}$ or $F g f r 1^{c k o} ; F g f r 2^{\text {cko }}$ mutants (Trokovic et al., 2005). In contrast, the ventral midbrain appeared completely negative for Fgfr1 expression. Thus, for the residual THpositive cells in the Fgfr ${ }^{c k o} ; F g f r 2^{\text {cko }}$ and $F g f r 1^{c k o} ; F g f r 2^{c k o} ; F g f r 3^{\text {null }}$ mutants, a mosaic receptor mutation is an unlikely explanation.

To further characterize the TH-positive cells in the ventral midbrain of $F g f r 1^{c k o} ; F g f r 2^{c k o}$ mutant embryos at E12.5, we analyzed the expression of LMX1A (marker of both proliferative progenitors and postmitotic precursors of DA neurons), HuC/D (general marker of postmitotic neural precursors), PITX3, TH, and Dat (postmitotic and mature DA neurons) on adjacent coronal sections by immunohistochemistry and in situ hybridization. Our results indicate that in the $F g f r 1^{c k o} ; F g f r 2^{\text {cko }}$ mutants, both the proliferative DA neuron progenitors (LMX1A+, HuC/D-) (supplemental Fig. $2 R$, available at www.jneurosci.org as supplemental material $)(p<0.005)$ and postmitotic precursors 
$(\mathrm{LMX} 1 \mathrm{~A}+, \mathrm{HuC} / \mathrm{D}+)$ are reduced (Fig. $4 K-N$; supplemental Fig. $2 R$, available at www.jneurosci.org as supplemental material) $(p<0.01)$. Interestingly, the cells positive for LMX1A, HuC/D, and $\mathrm{TH}$ failed to express PITX3 and Dat (Fig. 4O$R, S, U)$. Thus, in the Fgfr ${ }^{c k o} ; F g f r 2^{c k o}$ mutants, the maturation of the DA neurons is also disturbed.

Next, we studied the generation of DA neuron precursors at E10.5-E11.5. Aldh1 is one of the earliest specific markers of DA neurons, expressed in their proliferative progenitors, postmitotic precursors, and mature neurons (Wallen et al., 1999). Consistent with the observed r1-tomidbrain transformation, the Aldh1 expression shifted posteriorly in the $F g f r 1^{c k o}$; $\mathrm{Fgfr}^{\text {cko }}$ and $\mathrm{Fgfr} 1^{\text {cko }} ; \mathrm{Fgfr} 2^{\text {cko }} ; \mathrm{Fgfr} 3^{\text {null }}$ mutants at E10.5 and E11.5, but the overall amount of Aldh1-positive cells was clearly reduced (Fig. 5A-L). In agreement with the number of $\mathrm{TH}$-positive neurons at E12.5, the Aldh1 expression domain in the midbrain of the $F g f r 1^{\text {cko }} ; F g f r 2^{\text {cko }} ; F g f r 3^{\text {null }}$ embryos was consistently smaller than in the Fgfr1 $1^{c k o} ; F_{g f r} 2^{c k o}$ mutants (Fig. $5 C, D, I, J)$. Similarly to Aldh1, we detected very limited expression of Pitx 3 in the postmitotic DA neuron precursors in the E11.5 Fgfr ${ }^{\text {cko }} ; \mathrm{Fgfr}{ }^{\text {cko }}$ mutants (Fig. 5M$\mathrm{O})$. In conclusion, in the Fgfr ${ }^{\text {cko }} ; \mathrm{Fg} f \mathrm{~F}^{\text {cko }}$ and $F g f r 1^{c k o} ; F g f r 2^{c k o} ; F g f r 3^{\text {null }}$ embryos the amount of early DA neuron precursors is markedly reduced.

\section{Expression of proneural genes and ventral signaling molecules}

To test the hypothesis that decreased neurogenesis in the ventral midbrain could contribute to the loss of DA neurons, we analyzed the expression of proneural genes Ngn 2 and Mash1 (Fig. 6A-M). In the ventral midbrain of E10.5 Fgfr ${ }^{c k o} ; F_{g} f r 2^{c k o}$ mutants, they both were expressed at normal levels. Their expression had shifted posteriorly, likely as a result of the posterior shift of the midbrain-r1 border. This is in contrast to the Fgfr $1^{\text {cko }}$ mutants, which have a gap in Mash1 expression in the ventral r1 (Fig. 6J), possibly reflecting a failure in the differentiation of the most anterior serotonergic neurons (Jukkola et al., 2006). Analysis of Ngn2 and Mash1 expression on E11.5 coronal sections revealed an apparently normal dorsoventral expression pattern, as well (Fig. $6 G, H, L, M)$.

Consistent with the unaltered Ngn2 and Mash1 expression in the E11.5 Fgfr $1^{\text {cko }} ; F_{g f r} 2^{\text {cko }}$ mutants, Gata3 and Pou4f1 were also expressed in their correct ventrolateral domains (Fig. $6 N-W$ ). In
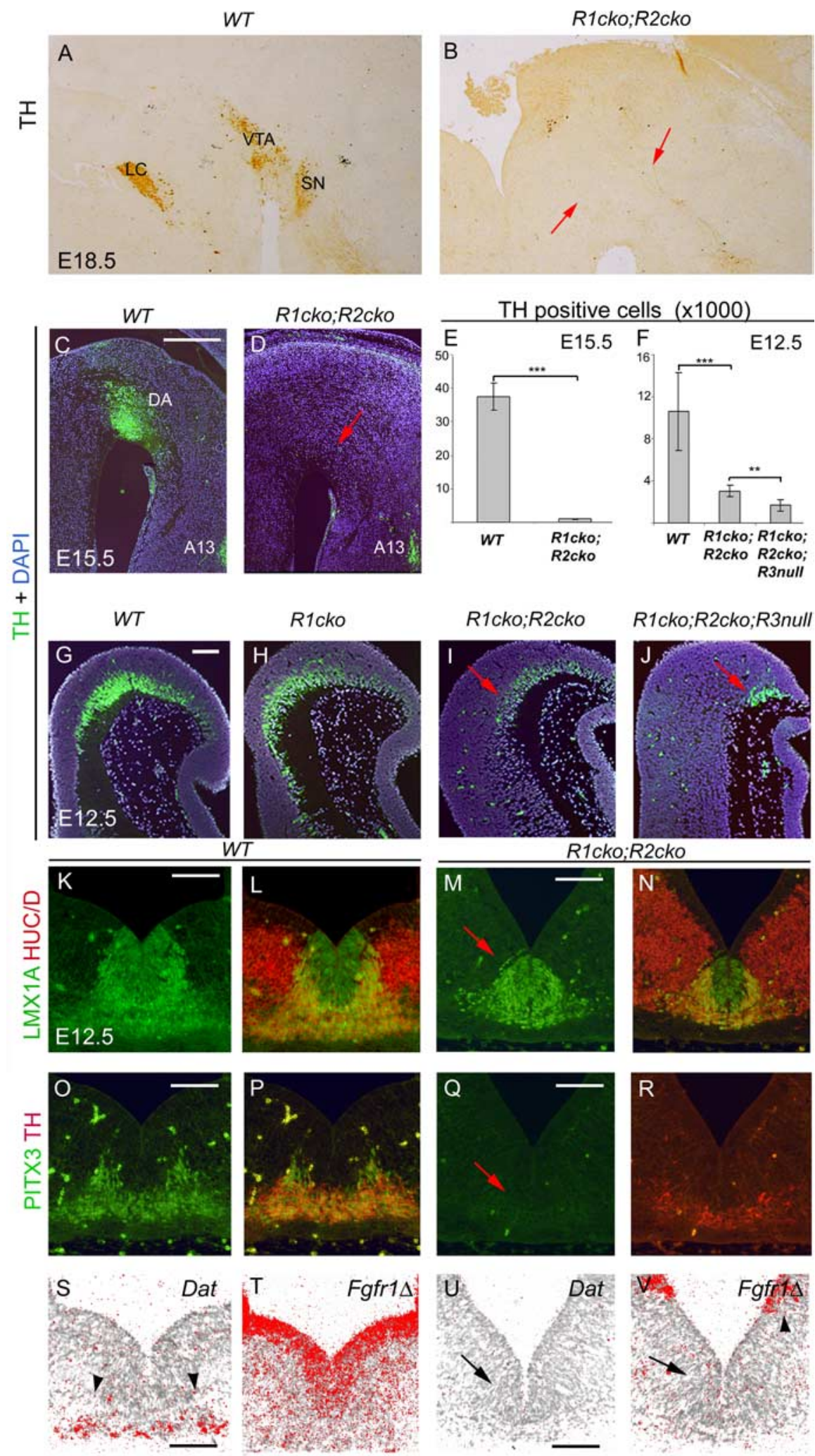

Figure 4. Failure in the development of the midbrain dopaminergic neurons. $\boldsymbol{A}-\boldsymbol{J}$, Immunohistochemical detection of TH expression

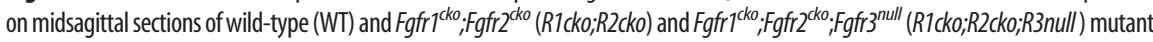
brains at E18.5 (A, B), E15.5 (C, D; quantification in $\boldsymbol{E}$; mean of total number \pm SD), and E12.5 (G-J; quantification in $\boldsymbol{F}$; mean of total number \pm SD). $\boldsymbol{K}-\boldsymbol{V}$, Immunohistochemical analysis of the expression of LMX1A $(\boldsymbol{K}, \boldsymbol{M}), \mathrm{LMX} 1 \mathrm{~A}$ plus HUC/D $(\boldsymbol{L}, \boldsymbol{N}), \operatorname{PITX}(\mathbf{0}, \mathbf{Q})$, and PITX3 plus TH $(\boldsymbol{P}, \boldsymbol{R})$, and in situ hybridization with Dat $(\boldsymbol{S}, \boldsymbol{U})$ and Fgfr $1 \Delta(\boldsymbol{T}, \boldsymbol{V})$ probes in WT and Fgfr ${ }^{\text {cko }}$;Fgfr2 ${ }^{\text {cko }}$ mutant embryos at E12.5. ${ }^{* *} p<0.01$ and ${ }^{* * *} p<0.001$, analyzed with Student's $t$ test. A13, DA cell group A13 in diencephalon; LC, locus ceruleus; SN, substantia nigra; VTA, ventral tegmental area. Red and black arrows indicate lost or decreased expression of DA markers or Fgfr1. Black arrowheads indicate DAT expression in WT ventral midbrain (S) and Fgfr 1 expression in dorsal tissue of the $F g f r 1^{\text {cko }} ; F_{\text {Ffr2 }}{ }^{\text {cko }}$ mutants (V). Scale bars: $\boldsymbol{C}$, $\boldsymbol{D}$ (in $\mathbf{C}), 500 \mu \mathrm{m} ; \boldsymbol{G}-\boldsymbol{V}$ (in $\mathbf{G}, \boldsymbol{K}, \boldsymbol{M}, \mathbf{0}, \mathbf{Q}, \mathbf{S}, \boldsymbol{U}), 100 \mu \mathrm{m}$. 

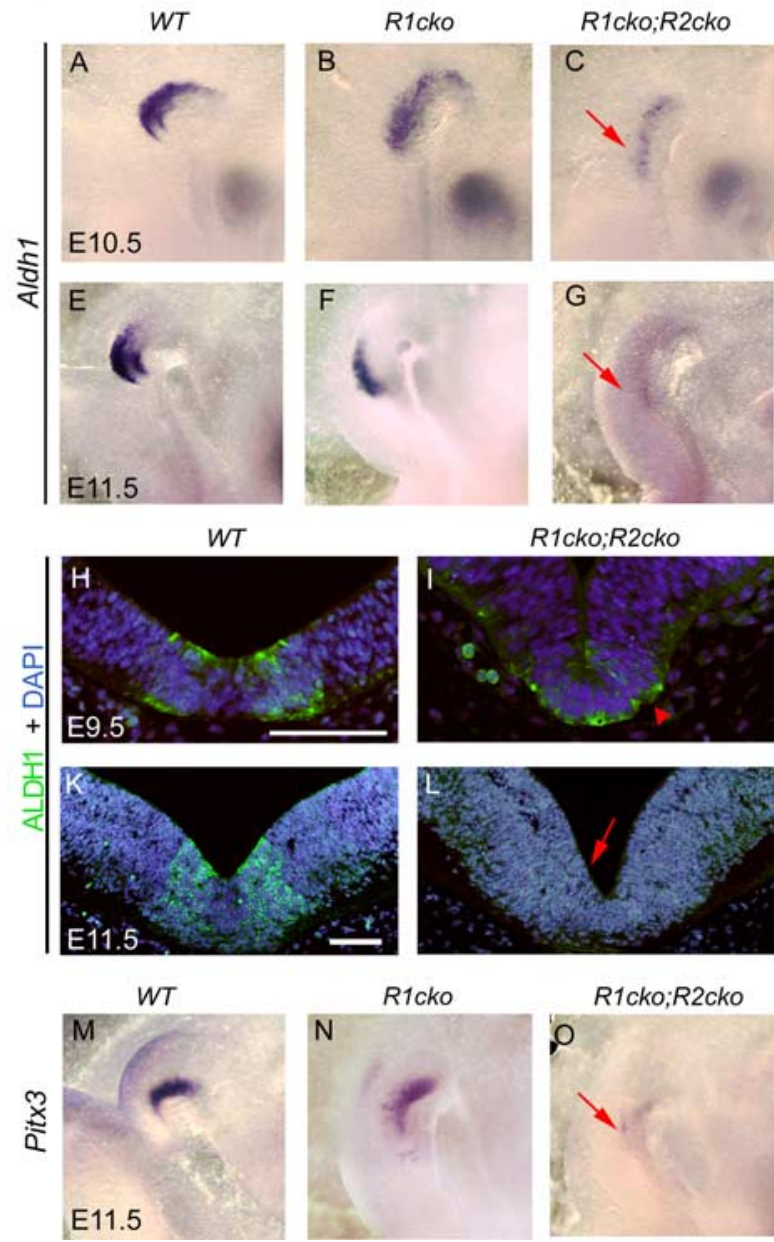

Figure 5. Early defects in the dopaminergic neuron precursors. $\mathbf{A}-\mathbf{G}, \mathbf{M - 0}$, Whole-mount mRNA in situ hybridization analysis

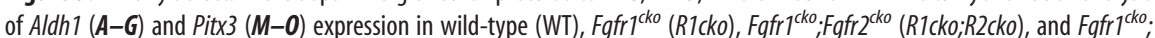
$\mathrm{Fgfr}^{\text {cko }}$;Fgfr $3^{\text {null }}$ (R1cko;R2cko;R3null) embryos. Lateral views (anterior rightwards) are shown. The embryos have been sagittally bisected after staining. $\boldsymbol{H}-\boldsymbol{L}, \mathrm{ALDH} 1$ immunohistochemistry on coronal sections at E9.5 and E11.5 in the WT, Fgfr ${ }^{\text {cko }}$; Fgfr $2^{\text {cko }}$, and $\mathrm{Fgfr}^{\mathrm{cko}}{ }^{\text {; Fgfr }}{ }^{\text {cko }}$; Fgfr ${ }^{\text {null }}$ embryos. Red arrows indicate changes in DA neurons and their precursors in the mutants. I, Red arrowhead shows residual ALDH1 expression. DAPI, 4',6'-Diamidino-2-phenylindole. Scale bars: (for $\boldsymbol{H}-\boldsymbol{J}) \boldsymbol{H}$, (for $\boldsymbol{K}, \boldsymbol{L}) \boldsymbol{K}, 100 \mu \mathrm{m}$.

Fgfr $2^{\text {cko }}$ mutants without major changes in the dorsoventral patterning, in the expression of transcriptional regulators of neurogenesis, or in the components of other signaling pathways regulating neuronal development in the ventral midbrain.

\section{Maintenance of proliferative neural progenitors in the ventral midbrain} We next studied whether the loss of FGF signaling results in a defect in the proliferative properties of neural progenitor cells. Both CyclinD1 (Fig. 8A,B,D,E) and $C y$ clinD2 (Fig. 8G,H) were downregulated dorsally, but not ventrally, in the midbrain-r1 region of the $F g f r 1^{c k o} ; F g f r 2^{c k o}$ embryos already at E9.0-E9.5. In the Fgfr1 ${ }^{\text {cko }}$; Fgfr $2^{\text {cko }} ; \mathrm{Fgfr} 3^{\text {null }}$ mutants, the downregulation of CyclinD1 was more pronounced and seen also in the ventral region both at E9.0 and E9.5 (Fig. 8C,F). Cyclin-dependent kinase inhibitor $p 21$ is normally expressed in a narrow midbrain-r1 boundary cell population dependent on FGF signaling (Trokovic et al., 2005). In E9.5 Fgfr ${ }^{\text {cko }}$;Fgfr2 ${ }^{\text {cko }}$ embryos, we could not detect any $p 21$ expression (Fig. 8I,J).

Cell proliferation and the maintenance of neural progenitor cell renewal in the developing spinal cord depend on SoxB1 transcription factors, expressed in the ventricular zone throughout the developing CNS (Pevny and Placzek, 2005). In addition, during the neural induction and the generation of the posterior CNS tissue, SoxB1 expression has been suggested to depend on FGF signaling (Streit et al., 2000; Wilson et al., 2000; Takemoto et al., 2006). Therefore, we hypothesized that FGFs from IsO might also regulate neuro-

contrast to the specific markers of the DA neuron precursors, Aldh1 and Pitx3, the expression level of other genes important for DA neuron development and maturation, such as Nurr 1, Lmx1b, and Lmxla (Andersson et al., 2006b), was unchanged at E10.5E11.5 in the $F g f r 1^{c k o} ; F g f r 2^{c k o}$ mutants (Fig. 6X-E) (data not shown).

To study whether the absence of FGF signaling affects other signaling pathways in the ventral midbrain region, we analyzed the expression of WNT and $\mathrm{SHH}$ pathway genes. In $\mathrm{Fg} f \mathrm{r}^{\text {cko }}$; $\mathrm{Fgfr}^{\text {cko }}$ and $\mathrm{Fgfr}^{\text {cko }} ; \mathrm{Fgfr}^{\text {cko }} ; \mathrm{Fgfr}{ }^{\text {null }}$ mutants, Wht1 was not expressed at the midbrain-r1 boundary either at E9.0 or E10.5, but interestingly the expression in the ventral and dorsal midbrain was still normal (Fig. 7A-D) (data not shown). Thus, the regulation of Wnt 1 expression in the IsO and ventral/dorsal midbrain presumably involves different mechanisms. Similarly to Wnt1, the expression of Drapc1 and Axin2, suggested targets of the canonical WNT pathway (Takahashi et al., 2002; Jukkola et al., 2004), still persisted in the ventral midbrain of the $F g f r 1^{c k o}$; Fgfr $2^{\text {cko }}$ mutants (Fig. $7 E-H, O, P$ ). Also, Shh and its target gene Gli1 were still abundantly expressed in the $F g f r 1^{\text {cko }} ; F_{g f r} 2^{\text {cko }} \mathrm{mu}$ tants (Fig. 7I-N). Together, these results demonstrate a marked reduction of the DA neurons and their precursors in the Fgfr ${ }^{\text {cko }}$; nal progenitor cell proliferation in the developing midbrain and r1 by maintaining SoxB1 expression. Consistent with this, Sox3 expression was downregulated already at E9.0 in the dorsal midbrain and $\mathrm{r} 1$ of the $F g f r 1^{c k o} ; \mathrm{Fg} f 2^{\text {cko }}$ embryos (Fig. $8 \mathrm{~K}-L$ ) and both dorsally and ventrally in the $F g f r 1^{\text {cko }} ; \mathrm{Fgfr} 2^{\text {cko }} ; \mathrm{Fg} f r 3^{\text {null }}$ mutants (Fig. 8M). At E9.5, Sox3 was downregulated in the ventral midbrain of both the $\mathrm{Fgfr}^{\text {cko }} ; \mathrm{Fgfr} 2^{\text {cko }}$ and the $\mathrm{Fgfr}{ }^{\text {cko }} ; \mathrm{Fgfr} 2^{\text {cko }}$; Fgfr $3^{\text {null }}$ mutants (Fig. $8 \mathrm{~N}-\mathrm{P}$ ).

To analyze the neuronal differentiation and cell-cycle exit in the ventral midbrain, we performed immunohistochemistry on coronal sections of E9.5-E11.5 wild-type, $F g f r 1^{c k o} ; F_{g} f 2^{c k o}$, and $F g f r 1^{c k o} ; F g f r 2^{c k o} ; F g f r 3^{\text {null }}$ embryos for SOX2 (marker of the proliferative ventricular zone progenitor cells) and HuC/D (marker of the postmitotic neural precursors) (Fig. $9 A-I$ ). In contrast to the wild-type embryos, in the Fgfr $1^{\text {cko }} ; \mathrm{Fgfr} 2^{\text {cko }} ; \mathrm{Fgfr} 3^{\text {null }}$ embryos the $\mathrm{HuC} / \mathrm{D}$-positive cells were abundant already at E9.5 (Fig. 9C). At E10.5 and E11.5, we detected more HuC/D-positive cells in both $\mathrm{Fgfr}^{\text {cko }} ; \mathrm{Fgfr} 2^{\text {cko }}(n=3)$ and $\mathrm{Fgfr}{ }^{\text {cko }} ; \mathrm{Fgfr} 2^{\text {cko }} ; \mathrm{Fgfr} 3^{\text {null }}(n=$ 2 ) embryos than in the wild type $(n=4)$. Concomitantly, the SOX2-positive ventricular zone was clearly thinner in the mutants $(p<0.001)$ (Fig. 9D-I,S; supplemental Fig S3A, available at www.jneurosci.org as supplemental material). Although the 
amount of SOX2-positive cells was reduced, the level of SOX2 expression per cell in mutant tissue was apparently similar to the wild type. In contrast, and consistent with its mRNA expression, the SOX3 protein expression in the E11.5 double- and triple-mutant embryos was strongly reduced, especially in the most ventral ventricular zone (Fig. 9J-L).

Other transcriptional regulators of the neural stem cell identity and potential targets of FGF signaling include the Hes family members Hes1, Hes3, and Hes5 (Hatakeyama et al., 2004). We found strong Hes 5 expression in the ventral midbrain ventricular zone of wild-type embryos. In the Fgfr ${ }^{c k o} ; \mathrm{Fgfr} 2^{c k o}$ and $F g f r 1^{c k o}$; Fgfr $2^{\text {cko }} ; \mathrm{Fgfr} 3^{\text {null }}$ embryos, the Hes5positive layer was clearly thinner than in the wild type, but the level of Hes5 expression was not reduced (Fig. $9 M-O$ ). In the most ventral ventricular zone, a small population of cells that were Hes5-negative yet SOX2-positive was detected (Fig. 9O) (data not shown). However, a similar gap in Hes5 expression existed in the posteroventral midbrain of the wild-type embryos. Similar to Hes5, Hes 1 was also expressed in the ventral midbrain of both wild-type and $F g f r 1^{c k o} ; F g f r 2^{c k o}$ embryos, but at relatively lower levels (supplemental Fig.S3C, available at www.jneurosci.org as supplemental material). Whereas Hes3 was expressed in other regions of the brain, we could not detect its expression in the E10.5-E11.5 ventral midbrain (data not shown).

To study the cell-cycle progression in the mutant embryos at E9.0 and E11.5, we analyzed BrdU incorporation (Fig. $9 P-R, T$; supplemental Fig S3, available at www.jneurosci.org as supplemental material) (data not shown). Although in the Fgfr $1^{c k o} ; F_{g f r} 2^{c k o}$ or the $F g f r 1^{c k o} ; F g f r 2^{c k o} ; F g f r 3^{\text {null }}$ mutants the total number of BrdU-positive cells was reduced, together with the thinning of the ventricular zone, the relative proportion of BrdUlabeled nuclei in the ventricular zone was not altered (Fig. 9P$R, T$; supplemental Fig. S3, available at www.jneurosci.org as supplemental material). In contrast to the wild-type embryos, in which the BrdU-labeled nuclei were located mostly in the basal region of the ventricular zone $(\mathrm{Z} 2)$ because of the interkinetic nuclear migration, in the mutant embryos the BrdU-positive nuclei were also abundant close to the ventricle (Z1).

Together, these results suggest that in the ventral midbrain of the Fgfr mutants, the proliferative neural progenitor population in the ventricular zone is gradually depleted. This is presumably caused by increased differentiation and decreased self-renewal, rather than a decreased rate of cell proliferation in the ventricular zone per se.

\section{Discussion}

In this study, we have analyzed the contributions of three FGF receptor genes, Fgfr1, Fgfr2, and Fgfr3, to the development of the midbrain and $\mathrm{r} 1$ in the mouse. Our results reveal cooperation
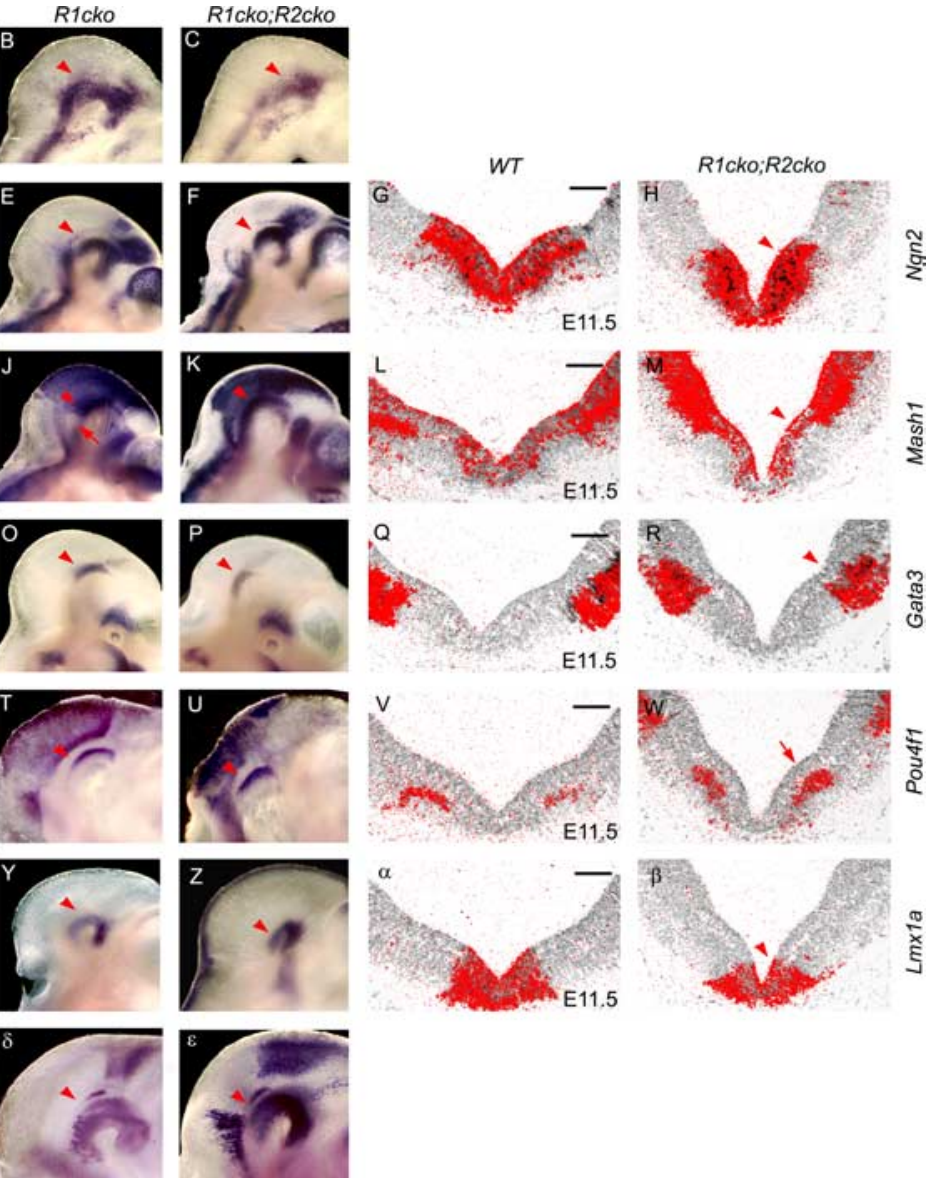

$\stackrel{\text { D }}{x}$

Figure 6. Expression of proneural genes and markers of the dorsoventral patterning. $\boldsymbol{A}-\boldsymbol{F}, \boldsymbol{I}-\boldsymbol{K}, \boldsymbol{N}-\boldsymbol{P}, \mathbf{S}-\boldsymbol{U}, \boldsymbol{X}-\boldsymbol{Z}, \boldsymbol{\chi}-\boldsymbol{\varepsilon}$, Whole-mount mRNA in situ hybridization analysis of $\mathrm{Ngn2}(\boldsymbol{A}-\boldsymbol{F})$, Mash1 (I-K), Gata3 (N-P), Pou4f1 (S-U), LmX1a (X-Z), and Nurr1 $(\boldsymbol{X}-\boldsymbol{\varepsilon})$ expression in the wild-type (WT), Fgfr ${ }^{\text {cko }}(R 1 c k 0)$, and Fgfr ${ }^{\text {cko }} ; F_{g f r}{ }^{\text {cko }}(R 1 c k 0 ; R 2 c k o)$ embryos at E9.5-E11.5. sections of E11.5 WT and $F g f r 7^{c k o} ; F g f r 2^{c k o}$ embryos with the probes indicated. $J, \boldsymbol{W}$, Red arrows indicate slightly upregulated Pou4f1 expression $(\boldsymbol{W})$ and Mash1 negative domain in the ventral $\mathrm{r} 1$ of $\mathrm{Fgfr}^{\mathrm{cko}}$ mutant $(\boldsymbol{J})$. Red arrowheads indicate gene expression still present in the mutants. Scale bars, $100 \mu \mathrm{m}$.

between the three Fgfrs and provide an explanation for the difference between the phenotypes of midbrain-r1-specific Fofrl and Fgf8 mutants (Chi et al., 2003; Trokovic et al., 2003). Supporting findings in the mouse, chicken, and zebrafish, we show that FGF signaling is involved in the regulation of cell survival and anteroposterior patterning in the midbrain-r1 region (Fig. 10A). In addition, we demonstrate that FGFR1, FGFR2, and FGFR3 together regulate neural progenitor cell properties in the ventral midbrain. We suggest that the loss of FGF signaling results in a failure to maintain normal SoxB1 expression and shifts the balance between the neural progenitor self-renewal and neuronal differentiation. Diverse intercellular signals probably regulate distinct behavioral aspects of precursor populations, such as midbrain DA neurons (for a model, see Fig. 10B).

FGFR1, FGFR2, and FGFR3 cooperate to receive survival and patterning signals from the IsO

Our results, together with recent analyses of FGF-FGFR associations (Olsen et al., 2006; Zhang et al., 2006), suggest that the three FGFRs expressed in the neuroectodermal cells receive FGF8/ FGF17/FGF18 signals from the isthmic organizer. Although all of these receptors are capable of binding the FGF8 subfamily members, they differ in their in vivo requirements. FGFR1, followed by FGFR2, is clearly the main receptor of the isthmic FGF signals. 

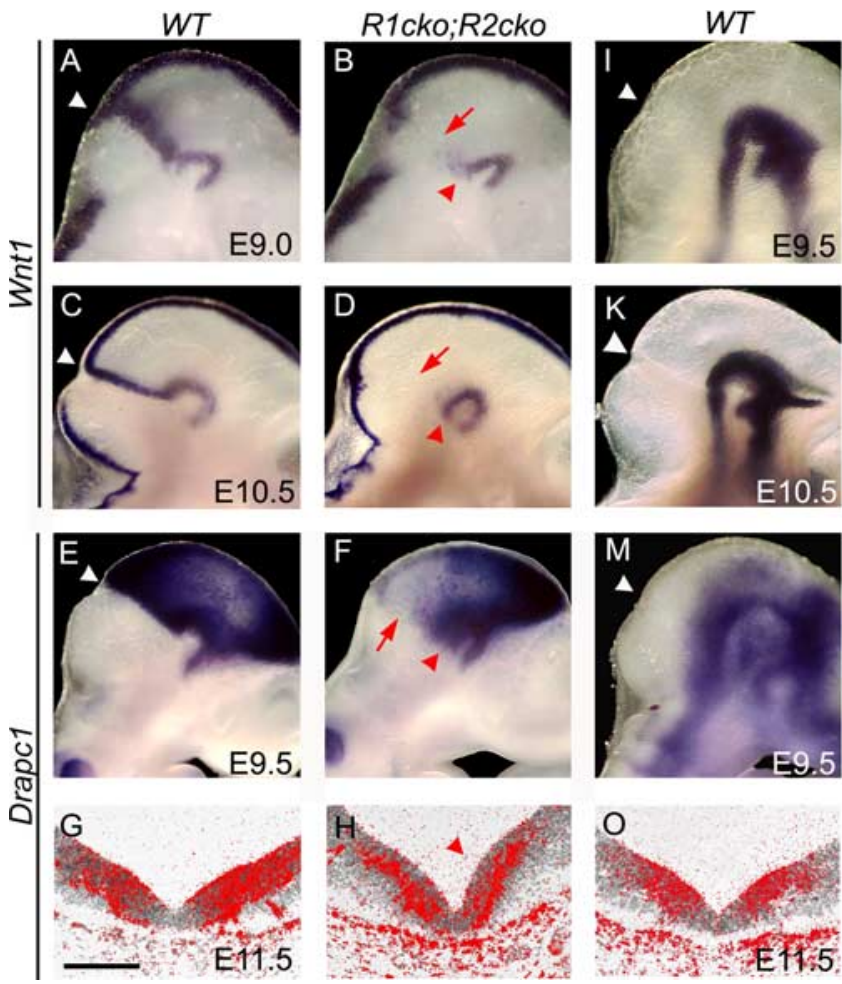

Figure 7. Unaltered ventral SHH and WNT1 signaling. $\boldsymbol{A}-\boldsymbol{P}$, Whole-mount $(\boldsymbol{A}-\boldsymbol{F}, \boldsymbol{I}-\boldsymbol{N})$ and radioactive $(\boldsymbol{G}, \boldsymbol{H}, \mathbf{0}, \boldsymbol{P})$ in situ hybridization analysis of $W n t 1(\boldsymbol{A}-\mathbf{D}), \operatorname{Drapc1}(\boldsymbol{E}-\boldsymbol{H}), \operatorname{Shh}(\boldsymbol{I}-\boldsymbol{K}), \mathrm{Gli1}(\boldsymbol{M}, \boldsymbol{N})$, and $A x i n 2(\boldsymbol{O}, \boldsymbol{P})$ in E9.0 -E11.5 wild-type (WT) and Fgfr $^{\text {cko }}{ }^{\text {; } F g f r 2 ~}{ }^{\text {cko }}(R 1 c k 0 ; R 2 c k 0)$ embryos. $\mathbf{G}, \boldsymbol{H}, \mathbf{O}, \mathbf{P}$, Coronal sections of ventral midbrain. Red arrowheads indicate the residual Wnt1 and Drapc1 expression in the ventral midbrain as well as unchanged expression of Shh, Gli1, and Axin2 in the mutant embryos. Red arrows visualize altered Wnt1 and Drapc1 expression at the midbrain-r1 boundary. Scale bar, $100 \mu \mathrm{m}$.

The contribution of FGFR3 is rather limited, being restricted to the ventral domain, and is revealed only when the two other receptors are inactivated. The diverse requirements for the FGFRs do not seem to reflect their FGF8 binding affinities, but rather their gene expression patterns (Walshe and Mason, 2000; Liu et al., 2003; Blak et al., 2005; Trokovic et al., 2005). The redundancy between the Fgfrs may not involve compensatory cross-regulation, because in the Fgfrl mutants the expression of Fgfr2 and Fgfr3 is unaffected (Trokovic et al., 2005; our unpublished observations).

The phenotype of the $F g f r 1^{\text {cko }} ; F g f r 2^{\text {cko }} ; F g f r 3^{\text {null }}$ mutants closely resembles that of the conditional Fgf8 mutants (Chi et al., 2003). In both cases, the same brain structures fail to develop, and cell death increases, especially on the dorsal side (alar plate) of the midbrain-r1 region. Instead of increased cell death, in the zebrafish Fgf8 mutants the isthmic region in the anterior $r 1$ transforms into midbrain identity (Jaszai et al., 2003). In the conditional Fgf8 mouse mutants, the posterior border of the midbrain, as determined by Otx2 expression, shifts slightly (Chi et al., 2003). Complementary to these results, strong ectopic FGF8 signaling activity in chicken and mouse embryos induces cerebellar development (Zervas et al., 2005). Our results support the conclusion that FGF signals from IsO maintain $G b x 2$ expression in the anterior $\mathrm{r} 1$ and thus restrict Otx2 expression and promote anterior $\mathrm{r} 1$ identity. Remarkably, even in the $\mathrm{Fgfr}^{\text {cko }} ; \mathrm{Fgfr}{ }^{\text {cko }} ; \mathrm{Fgfr} 3^{\text {null }} \mathrm{mu}-$ tants the entire $r 1$ was not deleted or transformed into Otx2positive tissue. This is similar to the phenotype of the zebrafish $\mathrm{Fgf8}$ mutants and suggests that the posterior $\mathrm{r} 1$ is unique in being less dependent on IsO-derived signals (Jaszai et al., 2003).
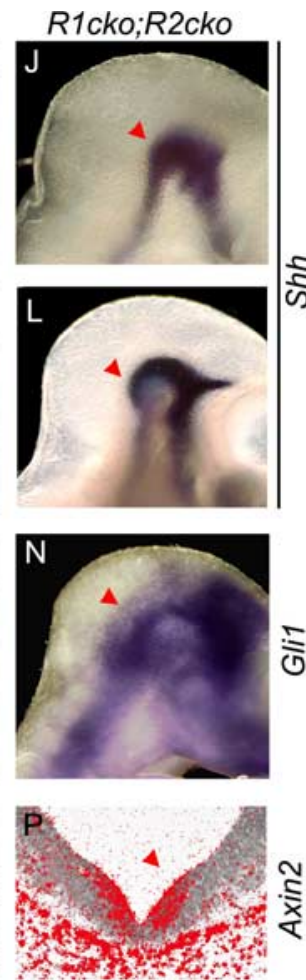

FGF signaling and development of the dopaminergic neurons

Neuronal differentiation in the ventral midbrain had defects without a loss of tissue or tissue identity, suggesting a more direct role for FGF signaling in the development of neuronal precursor cells themselves. Although Ye et al. (1998) recognized the ability of FGF8 and SHH to induce DA neuron development, the mechanisms involved are unclear. Our results with the $\mathrm{Fgfr}^{\text {cko }} ; \mathrm{Fgfr} 2^{\text {cko }}$ and $\mathrm{Fgfr} 1^{\text {cko }}$; Fgfr $2^{\text {cko }} ;$ Fgfr $3^{\text {null }}$ mutants demonstrate a marked reduction of DA neurons and their precursors. Apoptotic death in the ventral midbrain may contribute to the loss of DA neurons, but it can unlikely fully explain the loss, because increased apoptosis was prominent only dorsally. Furthermore, around the time of DA neuron induction and differentiation, genes such as Wnt1, Shh, Mash1, and Ngn2 were still expressed in the ventral midbrain of the mutants. This suggests apparently normal dorsoventral patterning and initiation of neurogenesis in the mutants.

The fact that in the Fgfr ${ }^{c k o} ; F g f r 2^{c k o}$ and Fgfr $1^{\text {cko }} ; F_{g f r} 2^{\text {cko }} ; \mathrm{Fgfr} 3^{\text {null }}$ mutants both early (Aldh1) and late (Pitx3, TH) markers of DA neurons were downregulated suggests that the defect is not in their later differentiation as in the Ngn2 and Nurr1 mutants (Wallen et al., 1999; Andersson et al., 2006a; Kele et al., 2006), but rather in the very early production of the DA neuron progenitors. Interestingly, Aldh1, an early marker of DA neuron precursors, and Pitx3, a marker of postmitotic precursors, are expressed as opposing gradients, where Aldh1 level is high posteriorly and Pitx3 anteriorly. This would be consistent with the reported anterolateral-to-posteromedial neurogenetic gradient of the mouse midbrain DA neurons (Bayer et al., 1995). Although FGF signaling is needed for the early development of the DA neuron precursors, this requirement does not appear to be absolute because few DA neurons began to develop even in the $F g f r 1^{\text {cko }}$; $F g f r 2^{c k o} ; F g f r 3^{\text {null }}$ embryos. As an alternative to the induction of the DA neuron identity, our results suggest that FGF signaling promotes the proliferative expansion of the early progenitor cell pool for DA neurons (see below).

In the $F g f r 1^{c k o} ; F g f r 2^{c k o}$ mutants, some $\mathrm{TH}$-positive neurons were detected at E12.5 but not anymore at E18.5. Interestingly, these cells fail to express many markers of mature DA neurons. Thus, FGF signaling may play a role later, in supporting the differentiation and maintenance of the DA neurons. Alternatively, the earlier developmental defects may secondarily lead into abnormal differentiation and neuronal loss.

\section{FGF signaling and maintenance of neural progenitor} cell renewal

In contrast to the cells close to the midbrain-r1 border (Trokovic et al., 2005), our data suggest that outside the narrow boundary region FGF signaling stimulates CyclinD expression. However, the loss of FGF signaling in the ventral midbrain ventricular zone did not block the S-phase entry. Instead, the balance between the 

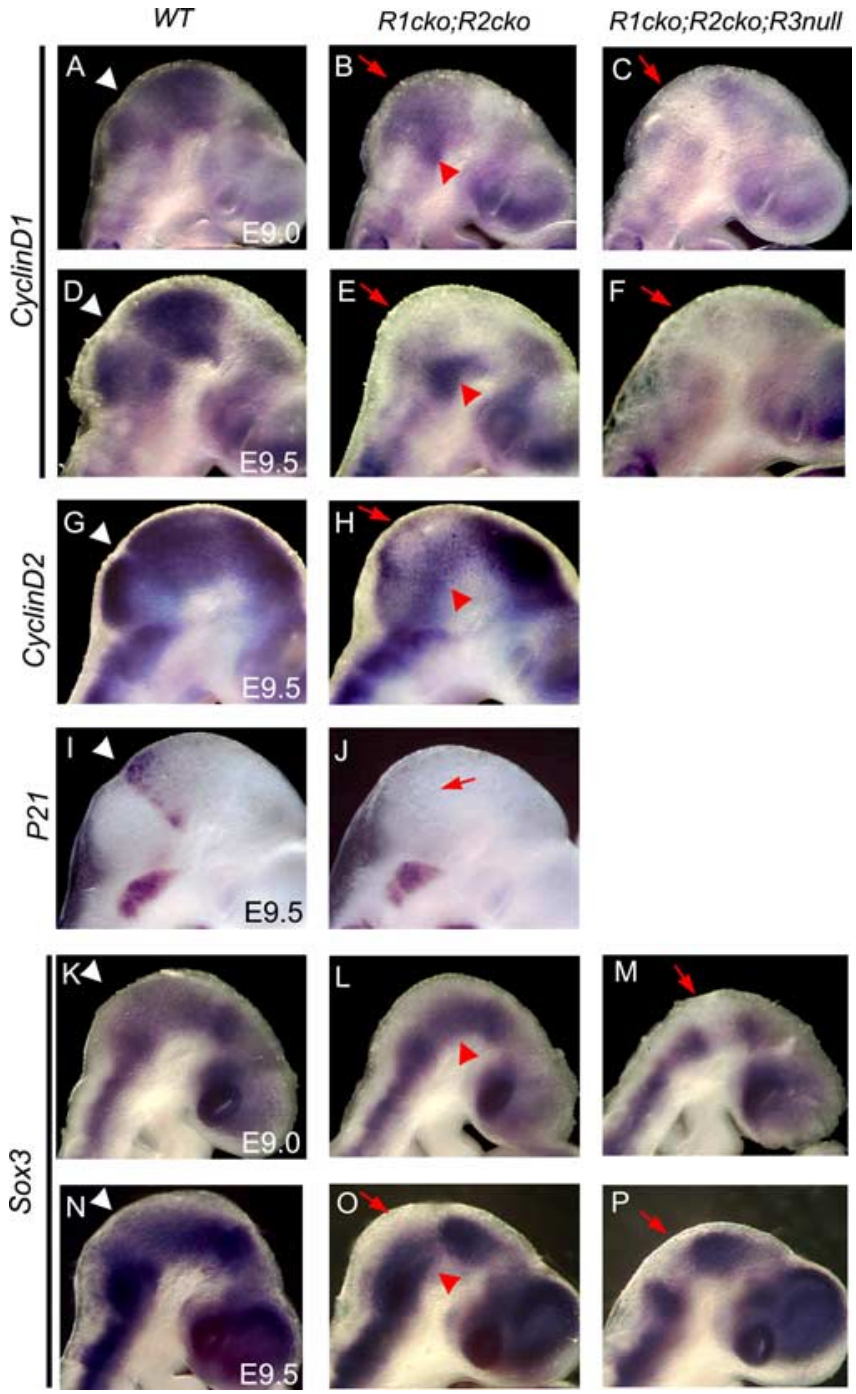

Figure 8. Decreased expression of the regulators of proliferative neural progenitor cells. Whole-mount mRNA in situ hybridization analysis of CyclinD1 $(\boldsymbol{A}-\boldsymbol{F}),(y \operatorname{clinD2}(\boldsymbol{G}, \boldsymbol{H}), p 21(\boldsymbol{I}, \boldsymbol{J})$,

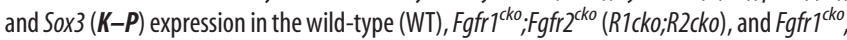
Fgfr2 $^{\text {cko }}$;Fgfr3 ${ }^{\text {null }}$ (R1cko;R2cko;R3null) embryos at E9.0-E9.5. Lateral views (anterior rightwards) are shown. Red arrows indicate downregulated (yclinD, p21, and Sox3 mRNA expression, whereas red arrowheads mark residual expression in the mutants.

progenitor self-renewal and postmitotic differentiation was clearly altered. In the spinal cord, the proliferative neural progenitor identity depends on SoxB1 (Sox1-3) transcription factors, which counteract the activity of proneural genes (such as Ngn2 and Mash1) and inhibit cell cycle exit and neuronal differentiation (Bylund et al., 2003; Graham et al., 2003). In the developing brain, however, the mechanisms by which the signaling centers regulate the balance between the neuronal progenitor cell selfrenewal and differentiation are poorly understood. Because especially Sox3 expression is sensitive to inactivation of FGF signaling, the FGF-mediated maintenance of the proliferative neural progenitors in the midbrain may involve the activity of SoxB1 transcription factors. Thus, FGFs may act through similar pathways during neural induction, posterior CNS elongation, and the development of the midbrain-r1 region. Interestingly, although Sox3 is broadly expressed throughout the early CNS, a local signaling center, IsO, strictly controls its expression in the midbrain and $\mathrm{r} 1$. Thus, despite the widespread expression, SOXB1 activity may be independently regulated in different parts of the developing CNS, as suggested also by enhancer mapping experiments (Brunelli et al., 2003). Given the viable phenotype of the Sox3 null mutants (Rizzoti et al., 2004), Sox3 is unlikely the only FGFinduced mediator of neural progenitor renewal. Other transcriptional regulators of the proliferative progenitor cell identity and potential FGF targets include Hairy and Enhancer of split-related transcription factors of the Hes family (Hirata et al., 2001; Ninkovic et al., 2005; Jukkola et al., 2006). However, our results suggest that in the ventral midbrain at least Hes5 and Hes 1 are unlikely critical transcriptional targets of FGF signaling.

Our results support a model in which the combinatorial actions of the intercellular signals guide the production of specialized neuronal subpopulations (Ye et al., 1998; Farkas et al., 2003; Prakash et al., 2006). Different signaling pathways, such as FGF, $\mathrm{WNT}$, and $\mathrm{SHH}$, may regulate distinct molecular cascades and aspects of cellular behavior (Fig. 9B). Although FGFs do not strictly control the expression of WNT and SHH signaling molecules themselves in the ventral midbrain, points of cross talk between the different pathways likely exist further downstream. For example, in cultured neural stem cells, WNT signaling alone (through $\beta$-catenin) promotes neuronal differentiation but stimulates cell proliferation in the presence of FGFs (Israsena et al., 2004). A similar mechanism might operate in the ventral midbrain, resulting in the DA neuron progenitor proliferation posteriorly close to the $\mathrm{IsO}$ and enhanced differentiation in more anterior regions, in which FGF signaling activity is lower.

\section{References}

Andersson E, Jensen JB, Parmar M, Guillemot F, Bjorklund A (2006a) Development of the mesencephalic dopaminergic neuron system is compromised in the absence of neurogenin 2. Development 133:507-516.

Andersson E, Tryggvason U, Deng Q, Friling S, Alekseenko Z, Robert B, Perlmann T, Ericson J (2006b) Identification of intrinsic determinants of midbrain dopamine neurons. Cell 124:393-405.

Bayer SA, Wills KV, Triarhou LC, Ghetti B (1995) Time of neuron origin and gradients of neurogenesis in midbrain dopaminergic neurons in the mouse. Exp Brain Res 105:191-199.

Blak AA, Naserke T, Weisenhorn DM, Prakash N, Partanen J, Wurst W (2005) Expression of Fgf receptors 1, 2, and 3 in the developing mid- and hindbrain of the mouse. Dev Dyn 233:1023-1030.

Blak AA, Naserke T, Saarimaki-Vire J, Peltopuro P, Giraldo-Velasquez M, Vogt Weisenhorn DM, Prakash N, Sendtner M, Partanen J, Wurst W (2006) Fgfr2 and Fgfr3 are not required for patterning and maintenance of the midbrain and anterior hindbrain. Dev Biol 303:231-243.

Brunelli S, Silva CE, Bell D, Harland R, Lovell-Badge R (2003) Expression of Sox 3 throughout the developing central nervous system is dependent on the combined action of discrete, evolutionarily conserved regulatory elements. Genesis 36:12-24.

Bylund M, Andersson E, Novitch BG, Muhr J (2003) Vertebrate neurogenesis is counteracted by Sox1-3 activity. Nat Neurosci 6:1162-1168.

Chi CL, Martinez S, Wurst W, Martin GR (2003) The isthmic organizer signal FGF8 is required for cell survival in the prospective midbrain and cerebellum. Development 130:2633-2644.

Colvin JS, Bohne BA, Harding GW, McEwen DG, Ornitz DM (1996) Skeletal overgrowth and deafness in mice lacking fibroblast growth factor receptor 3. Nat Genet 12:390-397.

Farkas LM, Dunker N, Roussa E, Unsicker K, Krieglstein K (2003) Transforming growth factor- $\beta(\mathrm{s})$ are essential for the development of midbrain dopaminergic neurons in vitro and in vivo. J Neurosci 23:5178-5186.

Graham V, Khudyakov J, Ellis P, Pevny L (2003) SOX2 functions to maintain neural progenitor identity. Neuron 39:749-765.

Hatakeyama J, Bessho Y, Katoh K, Ookawara S, Fujioka M, Guillemot F, Kageyama R (2004) Hes genes regulate size, shape and histogenesis of the nervous system by control of the timing of neural stem cell differentiation. Development 131:5539-5550.

Henrique D, Adam J, Myat A, Chitnis A, Lewis J, Ish-Horowicz D (1995) 

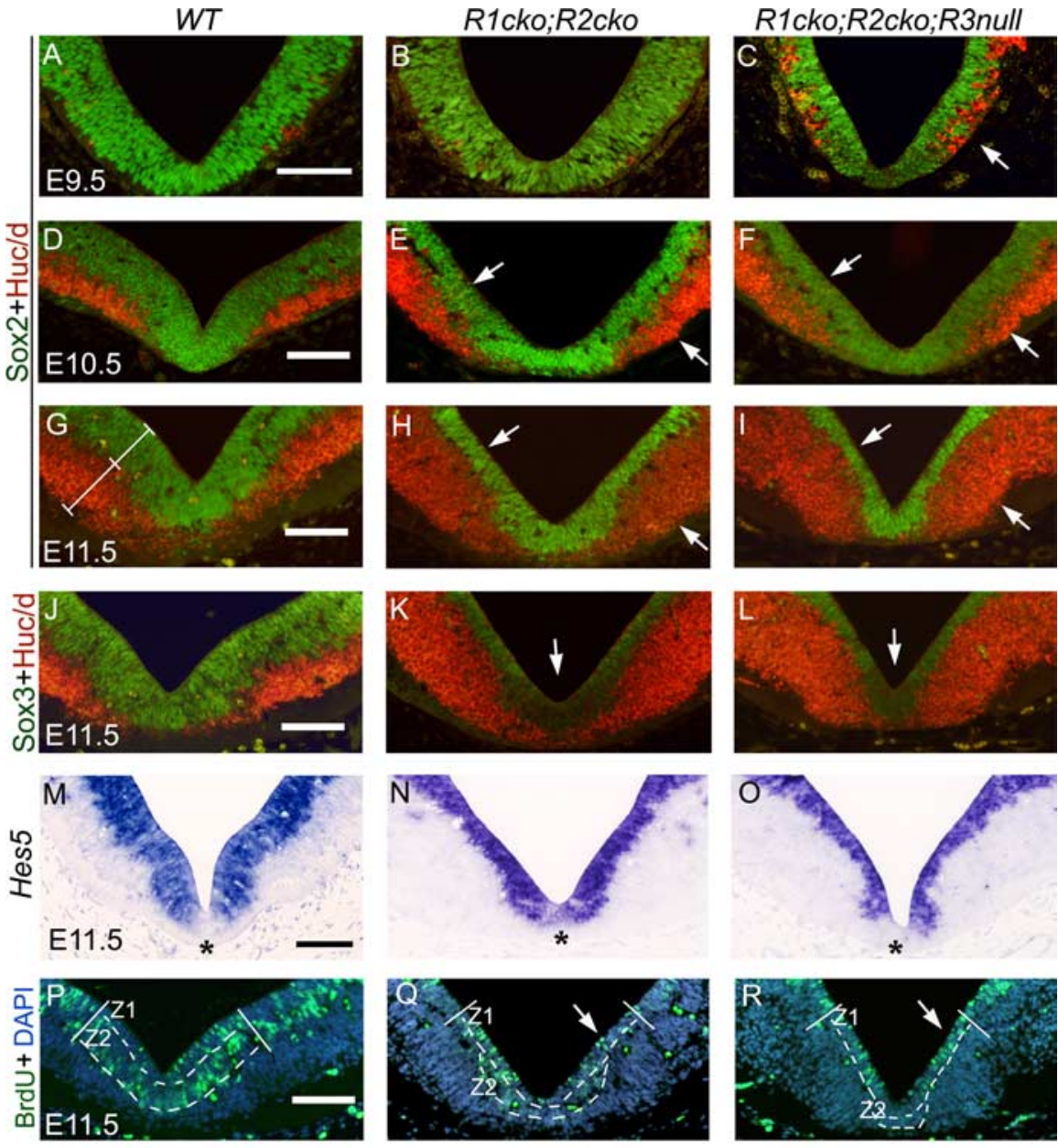

\section{S Thickness of Sox2 and Huc/d layers}

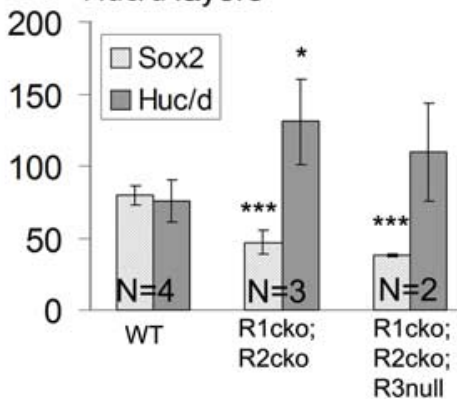

$\mathrm{T} \quad$ Labelling index of BrdU+ nuclei

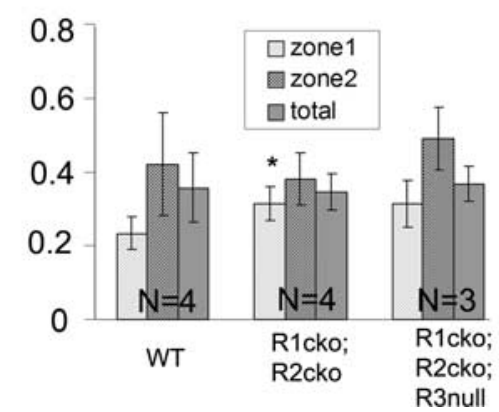

Figure 9. Premature postmitotic differentiation and depletion of proliferative neural precursor cells in the ventricular zone. $\boldsymbol{A}-\boldsymbol{R}$, Immunohistochemical analysis of SOX2 and HUC/D $(\boldsymbol{A}-\boldsymbol{I})$, SOX3 and HUC/D $(\boldsymbol{J}-\boldsymbol{L})$, and BrdU incorporation $(\boldsymbol{P}-\boldsymbol{R})$, as well as Hes5 5 nonradioactive in situ hybridization $(\boldsymbol{M}-\mathbf{0})$ on coronal midbrain sections of wild-type (WT), Fgfr ${ }^{\text {cko }} ; \mathrm{Fgfr2}{ }^{\text {cko }}(R 1 \mathrm{Cko} ; R 2 \mathrm{cko})$, and $\mathrm{Fgfr}^{\mathrm{cko}} ; \mathrm{Fgfr2}^{\mathrm{cko}} ; \mathrm{Fgfr}^{\text {null }}(\mathrm{R} 1 \mathrm{cko} ; \mathrm{R2} 2 \mathrm{cko} ; \mathrm{R3}$ null) embryos at E9.5-E11.5. S, The thickness of the ventricular zone (SOX2positive) and the marginal zone (HUC/D-positive) was quantified (mean \pm SD) at E11.5. G, The position at which layer thickness was measured is shown with white lines. For quantification of BrdU incorporation, the ventricular zone was divided into an approximately two-cell-layer-thick periventricular zone (zone1) and basal zone (zone2), visualized with broken lines (P-R). $\boldsymbol{T}$, The proportion (mean $\pm S D$ ) of BrdU-positive nuclei in zone1, zone2, and in the entire ventricular zone (total). White arrows point to decreased SOX2-positive layer and increased HUC/D-positive layer $(\boldsymbol{C}, \boldsymbol{E}, \boldsymbol{F}, \boldsymbol{H}, \boldsymbol{I})$, downregulated SOX3 expression $(\boldsymbol{K}, \boldsymbol{L})$, and periventricular BrdU-positive cells $(\boldsymbol{Q}, \boldsymbol{R})$ in the mutants. Z1, Zone1; Z2, zone2. Asterisks indicate Hes5-negative ventral domain. DAPI, $4^{\prime}, 6^{\prime}$-Diamidino-2-phenylindole. Scale bars, $100 \mu \mathrm{m} .{ }^{*} p<0.05$; $^{* * *} p<0.001$.

Expression of a Delta homologue in prospective neurons in the chick [see comments]. Nature 375:787-790.

Hirata H, Tomita K, Bessho Y, Kageyama R (2001) Hes1 and Hes3 regulate maintenance of the isthmic organizer and development of the mid/hindbrain. EMBO J 20:4454-4466.

Israsena N, Hu M, Fu W, Kan L, Kessler JA (2004) The presence of FGF2 signaling determines whether beta-catenin exerts effects on proliferation or neuronal differentiation of neural stem cells. Dev Biol 268:220-231.

Jaszai J, Reifers F, Picker A, Langenberg T, Brand M (2003) Isthmus-to-midbrain transformation in the absence of midbrain-hindbrain organizer activity. Development 130:6611-6623. Jukkola T, Sinjushina N, Partanen J (2004) Drapcl expression during mouse embryonic development. Gene Expr Patterns 4:755-762.

Jukkola T, Lahti L, Naserke T, Wurst W, Partanen J (2006) FGF regulated gene-expression and neuronal differentiation in the developing midbrain-hindbrain region. Dev Biol 297:141-157.

Kele J, Simplicio N, Ferri AL, Mira H, Guillemot F, Arenas E, Ang SL (2006) Neurogenin 2 is required for the development of ventral midbrain dopaminergic neurons. Development 133:495-505.

Kimmel RA, Turnbull DH, Blanquet V, Wurst W, Loomis CA, Joyner AL (2000) Two lineage boundaries coordinate vertebrate apical ectodermal ridge formation. Genes Dev 14:1377-1389.

Liu A, Li JY, Bromleigh C, Lao Z, Niswander LA, Joyner AL (2003) FGF17b and FGF18 have different midbrain regulatory properties from FGF8b or activated FGF receptors. Development 130:6175-6185.

Nakamura H, Katahira T, Matsunaga E, Sato T (2005) Isthmus organizer for midbrain and hindbrain development. Brain Res Brain Res Rev 49:120-126.

Ninkovic J, Tallafuss A, Leucht C, Topczewski J, Tannhauser B, Solnica-Krezel L, Bally-Cuif L (2005) Inhibition of neurogenesis at the zebrafish midbrain-hindbrain boundary by the combined and dose-dependent activity of a new hairy/E(spl) gene pair. Development 132:75-88.

Olsen SK, Li JY, Bromleigh C, Eliseenkova AV, Ibrahimi OA, Lao Z, Zhang F, Linhardt RJ, Joyner AL, Mohammadi M (2006) Structural basis by which alternative splicing modulates the organizer activity of FGF8 in the brain. Genes Dev 20:185-198.

Pevny L, Placzek M (2005) SOX genes and neural progenitor identity. Curr Opin Neurobiol 15:7-13.

Prakash N, Brodski C, Naserke T, Puelles E, Gogoi R, Hall A, Panhuysen M, Echevarria D, Sussel L, Weisenhorn DM, Martinez S, Arenas E, Simeone A, Wurst W (2006) A Wnt1regulated genetic network controls the identity and fate of midbrain-dopaminergic progenitors in vivo. Development 133:89-98.

Rhinn M, Picker A, Brand M (2006) Global and local mechanisms of forebrain and midbrain patterning. Curr Opin Neurobiol 16:5-12.

Rizzoti K, Brunelli S, Carmignac D, Thomas PQ, Robinson IC, Lovell-Badge R (2004) SOX3 is required during the formation of the hypothalamo-pituitary axis. Nat Genet 36:247-255.

Streit A, Berliner AJ, Papanayotou C, Sirulnik A, Stern CD (2000) Initiation of neural induction by FGF signalling before gastrulation. Nature 406:74-78.

Takahashi M, Fujita M, Furukawa Y, Hamamoto R, Shimokawa T, Miwa N, Ogawa M, Nakamura Y (2002) Isolation of a novel human gene, APCDD1, as a direct target of the beta-catenin/T-cell factor 4 complex 
with probable involvement in colorectal carcinogenesis. Cancer Res 62:5651-5656.

Takemoto T, Uchikawa M, Kamachi Y, Kondoh H (2006) Convergence of Wnt and FGF signals in the genesis of posterior neural plate through activation of the Sox 2 enhancer N-1. Development 133:297-306.

Trokovic R, Trokovic N, Hernesniemi S, Pirvola U, Vogt Weisenhorn DM, Rossant J, McMahon AP, Wurst W, Partanen J (2003) FGFR1 is independently required in both developing mid- and hindbrain for sustained response to isthmic signals. EMBO J 22:1811-1823.

Trokovic R, Jukkola T, Saarimaki J, Peltopuro P, Naserke T, Weisenhorn DM, Trokovic N, Wurst W, Partanen J (2005) Fgfr1-dependent boundary cells between developing mid- and hindbrain. Dev Biol 278:428-439.

Wallen A, Zetterstrom RH, Solomin L, Arvidsson M, Olson L, Perlmann T (1999) Fate of mesencephalic AHD2-expressing dopamine progenitor cells in NURR1 mutant mice. Exp Cell Res 253:737-746.

Walshe J, Mason I (2000) Expression of FGFR1, FGFR2 and FGFR3 during early neural development in the chick embryo. Mech Dev 90:103-110.

Wilkinson DG, Green J (1990) In situ hybridization and the three-dimensional construction of serial sections. In: Postimplantation mammalian embryos (Copp AJ, Cockroft DL, eds), pp 155-171. Oxford: Oxford UP.

Wilson SI, Graziano E, Harland R, Jessell TM, Edlund T (2000) An early requirement for FGF signalling in the acquisition of neural cell fate in the chick embryo. Curr Biol 10:421-429.

Wurst W, Bally-Cuif L (2001) Neural plate patterning: upstream and downstream of the isthmic organizer. Nat Rev Neurosci 2:99-108.

Xu J, Liu Z, Ornitz DM (2000) Temporal and spatial gradients of Fgf8 and Fgf17 regulate proliferation and differentiation of midline cerebellar structures. Development 127:1833-1843.

Ye W, Shimamura K, Rubenstein JL, Hynes MA, Rosenthal A (1998) FGF and Shh signals control dopaminergic and serotonergic cell fate in the anterior neural plate. Cell 93:755-766.

Yu K, Xu J, Liu Z, Sosic D, Shao J, Olson EN, Towler DA, Ornitz DM (2003) Conditional inactivation of FGF receptor 2 reveals an essential role for FGF signaling in the regulation of osteoblast function and bone growth. Development 130:3063-3074.

Zervas M, Blaess S, Joyner AL (2005) Classical embryological studies and
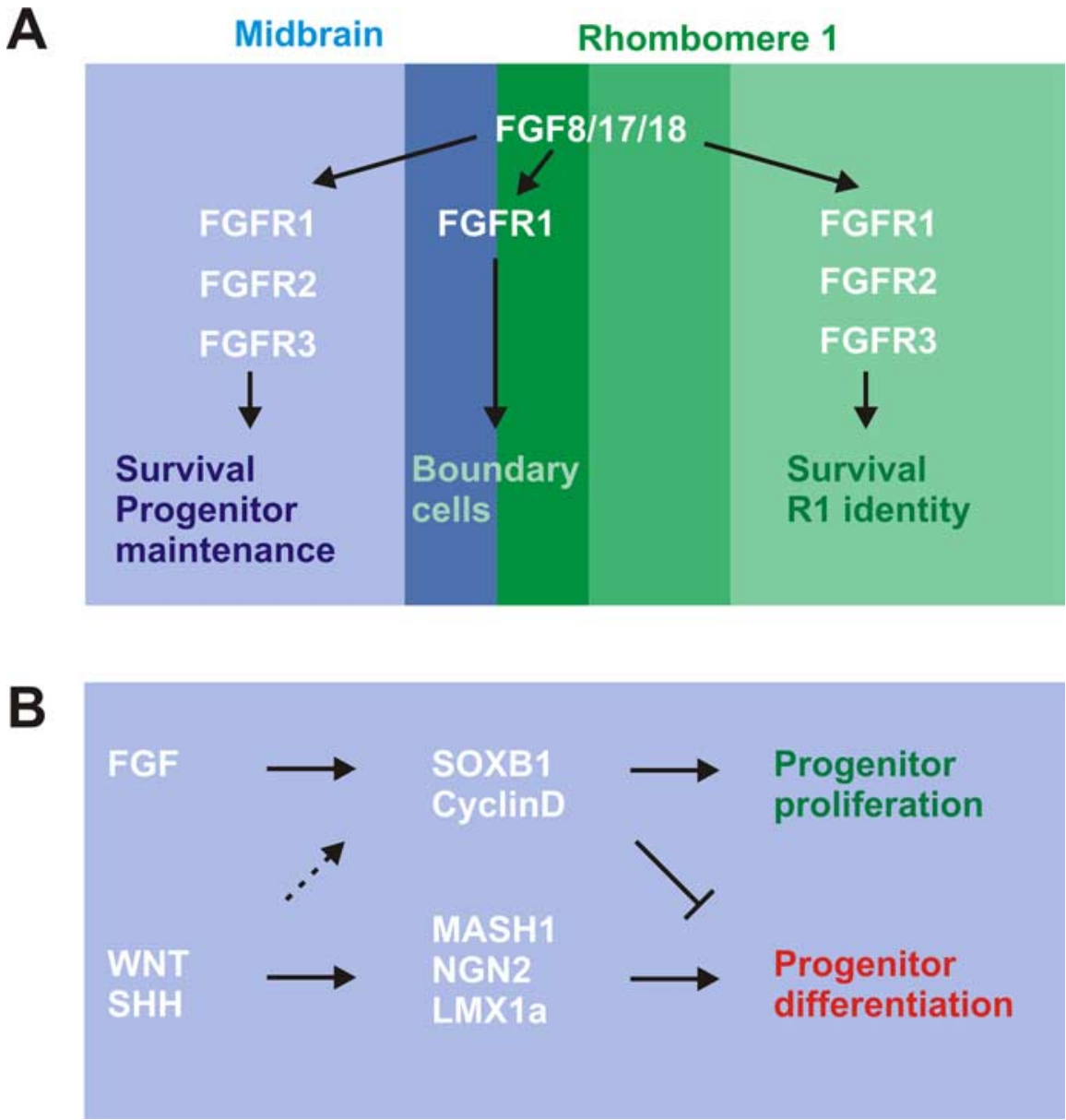

Figure 10. Model of FGFR cooperation and signal integration regulating cell behaviors in the midbrain-rhombomere 1 region. $A$, Cooperation of FGFRs. FGF8 subfamily members secreted predominantly from the anterior $r 1$ (dark green and medium green) act through three FGF receptors expressed in the midbrain-r1 region. FGFR1 is uniquely required for development of cell populations near the midbrain- $r 1$ border. These include specialized boundary cells in the most posterior midbrain (dark blue) and most anterior $\mathrm{r} 1$ (dark green) as well as serotonergic neuron precursors of the dorsal raphe. Together with FGFR2 and, to a lesser extent, FGFR3, FGFR1 also supports cell survival, promotes $r 1$ identity, and regulates the renewal of neural progenitor cells, including those of the midbrain DA neurons. $\boldsymbol{B}$, Model of signal interactions regulating precursor cell characteristics in the ventral midbrain. FGFs, expressed posteriorly, support the self-renewing neural progenitor cell identity, possibly through SOXB1 and CyclinD family members. Ventral signals, including WNT and SHH, regulate DA neuron identity and neuronal differentiation involving LMX1 family transcription factor and proneural gene expression. Posteriorly, these signals may cooperate with the FGF pathway to support progenitor cell proliferation (dashed arrow).

modern genetic analysis of midbrain and cerebellum development. Curr Top Dev Biol 69:101-138.

Zhang X, Ibrahimi OA, Olsen SK, Umemori H, Mohammadi M, Ornitz DM (2006) Receptor specificity of the fibroblast growth factor family. The complete mammalian FGF family. J Biol Chem 281:15694-15700. 